KuLTura - MeDia - TeoLogia

ISSN 2081-8971

$2017 \mathrm{nr} 30$, s. 70-100.

Karolina Świrska-Czałbowska-Instytut Edukacji Medialnej i Dziennikarstwa, Uniwersytet Stefana Kardynała Wyszyńskiego

\title{
Obraz Polski i Polaków w europejskim dyskursie publicznym. Analiza wyników badań opinii publicznej i artykutów z prasy zachodniej w latach 2004-2017
}

\section{The image of Poland and Poles in the European public discourse. Analysis of the results of polls and articles from the Western press in 2004-2017.}

\begin{abstract}
STRESZCZENIE:
Celem ARTyKuŁu JeST POKAZANIE WIZERUNKU Polski

I POLAKÓW W KRAJACH ,STAREJ UNII” ORAZ ZANALIZOWANIE JAK POLACY BYLI OCENIANI PRZED AKCESJĄ DO UNII EUROPEJSKIEJ W 2004 ROKU I JAK SĄ POSTRZEGANI OBECNIE. NINIEJSZE STUDIUM PRÓBUJE POKAZAĆ, CZY W WYNIKU WŁĄCZENIA POLSKI DO STRUKTUR EUROPEJSKICH WIZERUNEK NASZEGO KRAJU SIĘ ZMIENIŁ I NA ILE; JAK NASZA PONAD 13 LETNIA OBECNOŚĆ W STRUKTURACH UNIJNYCH WPŁYWA NA POSTRZEGANIE NASZEGO KRAJU ZARÓWNO WŚRÓD ELIT POLITYCZNYCH PAŃSTW UNIJNYCH, JAK I ZWYKŁYCH OBYWATELI. WYKORZYSTANE SĄ BADANIA OPINII PUBLICZNEJ, POLSKIE I MIĘDZYNARODOWE, JAK RÓWNIEŻ ARTYKUŁY PRASOWE, GŁÓWNIE Z PRASY ANGLOJEZYCZNEJ.

\section{SŁOWA KLUCZOWE:}

INTEGRACJA EUROPEJSKA, WIZERUNEK POLSKI, STEREOTYPY KULTUROWE, DYNAMIKA ZMIAN
\end{abstract}

\begin{abstract}
:
THE CONCEPT OF THIS PAPER IS TO PRESENT HOW POLAND AND POLISH PEOPLE WERE PERCEIVED IN "OLD" EU COUNTRIES PRIOR TO POLISH ACCESSION TO EUROPEAN UNION AND HOW POLISH PEOPLE WERE EVALUATED IN A CONTEXT OF "EASTERN ENLARGEMENT". ARTICLE ATTEMPTS TO FIND AN ANSWER WHETHER DUE TO POLISH INCLUSION IN EUROPEAN INSTITUTIONS, IMAGE OF POLAND HAS CHANGED AND HOW MUCH; HOW 13 YEARS LONG PRESENCE IN EU STRUCTURES INFLUENCED PERCEPTION OF OUR COUNTRY BOTH AMONGST EU POLITICAL ELITES AS WELL AS ORDINARY CITIZENS. THERE ARE USED BOTH PUBLIC OPINION POLLS, POLISH AND INTERNATIONAL, AS WELL AS PRESS ARTICLES, MAINLY FROM THE ENGLISH-LANGUAGE PRESS.
\end{abstract}

\section{KEYWORDS:}

European integration, Polish image, CUltural STEREOTYPES, DYNAMICS OF CHANGE 
„Europa to coś dalekiego, co trzeba osiągnąć, a co trzeba jeszcze zasłużyć.... To też coś cennego i z klasą: elegancki strój, szczególny wygląd i nawet zapach ludzi....”

Slavenka Drakulić „Cafe Europa”

$\mathbf{P}$ olska stała się członkiem Unii Europejskiej w maju 2004 roku. Dla społeczeństw dawnych krajów Unii, tak jak dla ich rządów, już od dawna było oczywiste, że rozszerzenie jej granic na wschód Europy postawi przed nią nowe wyzwania. Zmianom miała ulec sama Unia Europejska w ówczesnym kształcie, jak również zasady jej funkcjonowania, co powodowało spore obawy wśród mieszkańców wielu państw unijnych. Obawy i wątpliwości były obecne po obu stronach - zarówno po stronie krajów kandydackich, jak i krajów dawnej UE-15. Dlatego warto starać się pokazać, jaki był wizerunek Polski i Polaków w krajach „starej Unii” na tle uwarunkowań „wschodniego rozszerzenia”, a także odpowiedzieć na pytanie, jak zmienił się on w wyniku włączenia Polski do struktur europejskich.

Wcześniejsze rozszerzenia - „północne” z 1973 roku, „południowe” z 1981 i 1986 roku oraz „państw neutralnych” z 1995 roku nie wzbudzały tylu kontrowersji. Do silnej i bogatej Unii weszły kraje nieróżniące się znacznie od państw członkowskich poziomem zamożności i rozwoju cywilizacyjnego (w szczególności przy rozszerzeniu „północnym” i „państw neutralnych” różnice nie były tak istotne). Przy okazji rozszerzenia „wschodniego” z 2004 roku sytuacja była inna: do Unii dołączyły kraje, które dopiero kilkanaście lat wcześniej weszły na zachodnią ścieżkę rozwoju i wciąż nie dorównywały państwom unijnym ani pod względem stanu gospodarki, ani dojrzałości politycznej, czy politycznych tradycji.

Również kryteria oceny państw kandydatów zostały poddane wielu zmianom i weryfikacjom. Jak pisała Lena Kolarska-Bobińska w przededniu integracji: „coraz większą rolę w procesie integracji zaczyna też odgrywać polityka oraz 'miękkie', pozaprawne kryteria oceny kandydatów, niepisane i zmieniające się racje, u podłoża których często leżą stereotypy krajów i społeczeństw, czy tradycje historycznych relacji między państwami. W tej sytuacji kluczowe staje się określenie, jaki wizerunek Polski i Polaków funkcjonuje obecnie w krajach Unii, gdyż sprzyja to prowadzeniu właściwej polityki informacyjnej i lobbingu, jak również dlatego, że integracja oznacza przede wszystkim bliskie współdziałanie społeczeństw, regionów, organizacji. (...) Sposobem poprawy pozycji naszego kraju jest zmiana wizerunku Polski. Postrzeganie rzeczywistości odgrywa bowiem równie istotną rolę jak "twarde« fakty, wskaźniki i liczby"12.

Wally Olins - brytyjski specjalista od marketingu narodowego iszef Saffron Brand Consultants - firmy, która wraz z Instytutem Marki Polskiej pracowała nad zmia-

\footnotetext{
${ }^{1}$ L. Kolarska-Bobińska, Obraz Polski i Polaków w Europie, wyd. Instytut Spraw Publicznych, Warszawa 2003, s. 10.

${ }^{2}$ W. Olins, Tożsamość rynkowa. Atrybut konkurencyjnego Państwa, wyd. Instytut Marki Polskiej, Warszawa 2001, s. 133-164.
} 
ną wizerunku Polski twierdził, że dobra marka przedsiębiorstwa jest częścią jego majątku, wartością przeliczaną na zysk. Również przemyślany oraz dopracowany wizerunek kraju pełni kluczową rolę w gospodarczych i politycznych kontaktach między państwami. Bez niego trudno jest zdobyć zaufanie inwestorów zagranicznych i zaistnieć na arenie międzynarodowej. Główne tezy Olinsa są następujące:

1. W dzisiejszym świecie są trzy najważniejsze płaszczyzny gospodarczej rywalizacji między państwami: pozyskiwanie inwestycji zagranicznych, turystyka oraz eksport towarów i usług.

2. Zdecydowana większość krajów i regionów, które zdołały przyciągnąć inwestycje zagraniczne realizowała przemyślane strategie promocyjne, kreując planowo swój wizerunek (przykład Walii i Irlandii).

3. Stereotypy dotyczące kraju mogą w znacznym stopniu wpływać na możliwość rozwoju państw. Zbudowanie 'pozytywnego stereotypu' może uczynić miejsce pochodzenia produktu atutem wzabieganiu orynki zbytu (Brazylia).

4. W turystyce panuje ogromna konkurencja cenowa. Nie wystarcza już atrakcyjne położenie geograficzne ani piękno natury - kraje próbujące przyciągnąc turystów muszą się wyróżniać. Używając tych samych technik, co producenci dóbr konsumpcyjnych, muszą pokazać to, co czyni je wyjątkowymi (Portugalia).

5. Państwa konkurują między sobą używając nowoczesnych narzędzi marketingowych. Sukces komercyjny zależy do tego, czy wizerunki dotyczące inwestycji zagranicznych, eksportu i turystyki są spójne, wzajemnie się spierają. Dlatego tak ważne jest planowanie, koordynacja i systemowe zarządzanie marką narodową (przykłady całościowej polityki wizerunkowej: Hiszpania, Wielka Brytania). ${ }^{3}$

Niestety, Polska w momencie akcesji do Unii nie mogła poszczycić się dobrym obrazem samej siebie ani u sąsiadów, ani u dalszych państw zachodniej Europy. I nie tylko Polska. Mimo, że po upadku systemu komunistycznego społeczeństwa krajów byłego bloku wschodniego zaczęły popierać idee demokratyczne, przez fatalny stan swojej gospodarki zyskały odrębny status od krajów Europy Zachodniej. Nawet w oficjalnym nazewnictwie Unii kraje Europy Środkowowschodniej zaczęto je określać jako „drugą Europę” (,the other Europe”). Znalazło to wyraz w nastrojach podsumowujących politykę WE wobec krajów kandydackich. Andras Koves zauważył, że:

„Wspólnym problemem państw regionu Europy Środkowo-Wschodniej jest konieczność współistnienia i funkcjonowania watmosferze, którą uznają jako za stosunkowo lekceważącą. Wszystkie prognozy i podsumowania dają im odczuć, że nie są tak ważne dla reszty świata (który według ich światopoglądu oznacza Świat Zachodu), jakby sobie tego życzyły". ${ }^{4}$

\footnotetext{
${ }^{3}$ Tamże.
} 


\section{Wizerunek krajów Europy Środkowo-Wschodniej w krajach dawnej Unii Europejskiej (UE -15) w momencie akcesji do UE}

Dziedzictwo Europy Środkowo-Wschodniej utożsamiane było z dziedzictwem konfliktów i resentymentów (np. problem niemiecki), brakiem tradycji politycznej (t.j. pluralizm, debata), zacofaniem ekonomicznym (brak przedsiębiorczości, wtórność, a nie endogeniczność rozwoju). Różnice w kulturze politycznej (brak stabilności, częste zmiany rządów, konflikty pomiędzy społeczeństwem, a klasą polityczną) bardzo niekorzystnie wpływały na obraz krajów Europy Wschodniej. Te cechy sprawiły, że elity Zachodu po roku 1989 z nieufnością odnosiły się do elit politycznych Europy Wschodniej. Sytuację porównywano do pierwszych lat powojennych w Niemczech i Włoszech, kiedy brakowało tam porządku i harmonii w życiu publicznym, a zmęczone wojną społeczeństwa wykazywały sympatie w kierunku sił antydemokratycznych.

Zasadnicze różnice i niedociągnięcia, jakie wypominano krajom Europy ŚrodkowoWschodniej można podzielić na polityczno-społeczne, gospodarcze i infrastrukturalne.

Do kwestii polityczno- społecznych zaliczano: odmienność kultury politycznej, brak stabilizacji na scenie politycznej, brak zaufania do elit politycznych - jako dziedziców postkomunizmu i niewiarygodnych partnerów do dyskusji, również nieprzewidywalność opinii publicznej. Kolejną kwestią miała być przestarzała struktura społeczna i zawodowa Polski, powstała w wyniku dominacji gospodarki nakazowo-rozdzielczej, która nie przystawała do wymagań gospodarki kapitalistycznej i wolnego rynku. Uznano, że zbyt wysoka liczba osób pracuje w sektorze rolnictwa i przemysłu, przy niskiej roli sektora usług, a także zawodów nowoczesnych (tj. biznes, bankowość, ubezpieczenia, obrót nieruchomościami, itp.). Przestarzałe i mało wydajne polskie rolnictwo wymagać miało nie tylko dużych nakładów z Unii, ale i ze środków własnych Polski. Wskazywano również rozbudowane państwowe systemy biurokratyczne, niskie płace pracowników, niską siłę nabywczą ludności, pasywny stosunek do pracy. ${ }^{5}$ Warunki wymagane przez rynek europejski wymusić miały modernizację struktury zawodowej polskiego społeczeństwa, co spowodować miało dodatkowe koszty społeczne.

Do różnic gospodarczych zaliczano: przestarzałą strukturę gospodarki, produkcję przemysłową ocenianą na 30-50\% poniżej standardów wymaganych w państwach UE -15, nadmierne zużycie materiałów i energii, zyskowność produkcji znacznie niższą niż na Zachodzie, niestabilne rynki finansowe. Wskazywano także na braki nowoczesnej infrastruktury: zbyt mała liczba dróg, niedorozwój transportu śródlądowego i lotniczego, zły stan sieci telekomunikacyjnych, a także lekceważenie zasad ochrony środowiska.

Kolejną barierą było niedostosowanie prawa do reguł gospodarki rynkowej i zadłużenie zagraniczne, które w roku 1989 w przypadku krajów Europy Środkowo-Wschodniej wy-

\footnotetext{
${ }^{4}$ A. Koves, Central and Eastern European Economies in Transition. The International Dimension, Westview Press, San Francisco 1992.

${ }^{5}$ Szerzej por. E. Wnuk-Lipiński, Członkostwo Polski w Unii Europejskiej-pierwsze Problemy i kryzysy społeczne w Polsce, w: Polska w Unii Europejskiej. Początkowe problemy i kryzysy?, wyd. PISM Warszawa 2002.
} 
liczono na 99,2 mld dolarów (zadłużenie Polski szacowano na 40,4 mld dolarów i 1078 dolarów per capita, Węgier 19,7 mld dolarów i 1873 dolarów per capita, a Czechosłowacji 6,9 mld dolarów i 431 dolarów per capita). ${ }^{6}$ Obawiano się również, że dla polskich firm barierą uniemożliwiającą wejście dla ich produktów na europejskie rynki będą unijne standardy jakości, którym sprostanie nie będzie możliwe bez uprzednich zmian modernizacyjnych i nakładów inwestycyjnych. Ważne były również kwestie gospodarki terenów przygranicznych, zwłaszcza ściany wschodniej, która przez odcięcie i uszczelnienie granicy miała zostać pozbawiona stałej możliwości zarobkowania. Ukrócenie „szarej strefy” handlu przygranicznego miało dla terenów ściany wschodniej okazać się ciosem w ich interesy ekonomiczne i spowodować opór tej części ludności przeciwko dalszym zmianom.

Wszystkie te problemy opóźniały negocjacje i przyjęcie krajów Europy ŚrodkowoWschodniej do Unii Europejskiej. Dano im do zrozumienia, że zgoda na ich członkostwo w Unii zależna będzie od stanu przygotowań i spełnienia warunków polityczno-gospodarczych wyznaczonych przez UE.

Jakie wobec tego czynniki przemawiały za przyjęciem tych krajów do UE?

Wskazywano na wzrost zagrożenia bezpieczeństwa w Europie jako efekt zaniechania współpracy z krajami Europy Środkowo-Wschodniej. Obawiano się wybuchu konfliktów i rozruchów w tej części Europy oraz zakładano, że rządy Zachodu będą zmuszone w nie zaingerować. Za bliższą współpracą przemawiała również perspektywa zdobycia rynku kilkudziesięciu milionów nowych konsumentów dla produktów zachodnioeuropejskich i tańszej siły roboczej dla europejskiego przemysłu. Korzyści, wypływające ze zwiększonej wymiany handlowej i ze wzrostu gospodarczego w krajach wschodnich miały być widoczne w całej Europie, nie tylko w krajach nowoprzyłączonych. Nie bez znaczenia były związki kulturowe i historyczne państw Europy Środkowo-Wschodniej, przemawiające za przyłączeniem ich do Unii. Uważano, że Unia, dysponująca liczbą 25 członków zwiększyłaby jeszcze swój potencjał polityczny na arenie międzynarodowej.

\section{„Witajcie w Unii, jeśli musicie”, czyli społeczeństwa dawnych krajów członkowskich wobec poszerzenia} Ponieważ akceptacja dla procesu integracji w państwach członkowskich była jednym z celów polityki informacyjnej UE, regularnie prowadzono badania monitorujące stosunek do procesu integracji w społeczeństwach dawnych i nowych krajów UE. Jak opisywał prof. J. Holzer „punktem wyjścia dla analiz wzajemnych wizerunków powinna być daleko posunięta asymetria. Kultura, przemiany polityczne i cywilizacyjne krajów Europy Zachodniej były i są u nas obserwowane i analizowane z dużym zainteresowaniem. Natomiast kultura polska i zmiany, jakie na bieżąco zachodzą w Polsce, jak również innych krajach wyszehradzkich traktowane były na zachodzie w zainteresowaniach marginalnie, raczej jako element egzotyki niż równoprawnego sąsiedztwa".

Społeczeństwa dawnych krajów członkowskich Unii, zupełnie inaczej niż społeczeństwa krajów aspirujących do Unii postrzegały przyjęcie do niej krajów Europy Wschodniej.

$6 \quad$ Cyt. za: B. Płonka, Polityka Unii Europejskiej wobec krajów Europy Srodkowej, wyd. UJ Kraków 2003, s. 59.

${ }^{7}$ J. Holzer, Polacy i Niemcy - wzajemne postrzeganie, Kultura i społeczeństwo, tom XLI, wyd. ISP PAN 1997. 
Tab.1. Problematyka dotycząca rozszerzania Unii Europejskiej

\begin{tabular}{|l|l|l|l|}
\hline Twierdzenie & Zgadzam się & $\begin{array}{l}\text { Nie zgadzam } \\
\text { się }\end{array}$ & $\begin{array}{l}\text { Trudno po- } \\
\text { wiedzieć }\end{array}$ \\
\hline $\begin{array}{l}\text { Im więcej państw będzie należeć do Unii, tym większe będzie } \\
\text { jej znaczenie w świecie }\end{array}$ & $67 \%$ & $17 \%$ & $16 \%$ \\
\hline $\begin{array}{l}\text { Mając więcej członków w Unii, Europa będzie bogatsza kultu- } \\
\text { ralnie }\end{array}$ & $61 \%$ & $31 \%$ & $8 \%$ \\
\hline $\begin{array}{l}\text { Większa liczba członków oznacza większa gwarancję pokoju } \\
\text { i bezpieczeństwa w Europie }\end{array}$ & $59 \%$ & $25 \%$ & $16 \%$ \\
\hline $\begin{array}{l}\text { Przed włączeniem nowych członków Unia musi zreformować } \\
\text { działalnośc swoich instytucji }\end{array}$ & $59 \%$ & $16 \%$ & $25 \%$ \\
\hline $\begin{array}{l}\text { Rozszerzenie Unii o nowych członków oznacza zmniejszenie } \\
\text { pomocy finansowej dla mojego kraju }\end{array}$ & $47 \%$ & $26 \%$ & $27 \%$ \\
\hline $\begin{array}{l}\text { Im więcej krajów znajdzie się w Unii, tym większe bezrobocie } \\
\text { w moim kraju }\end{array}$ & $35 \%$ & $41 \%$ & $24 \%$ \\
\hline $\begin{array}{l}\text { Powiększenie Unii o nowe kraje oznacza zmniejszenie znacze- } \\
\text { nia mojego kraju w Europie }\end{array}$ & $34 \%$ & $47 \%$ & $19 \%$ \\
\hline $\begin{array}{l}\text { Powiększenie Unii nie oznacza większych kosztów dla obec- } \\
\text { nych jej członków }\end{array}$ & $28 \%$ & $49 \%$ & $23,00 \%$ \\
\hline
\end{tabular}

Żródło: Eurostat Yearbook 2001. The Statistical Guide to the Europe, Data 1989-1999 ${ }^{8}$.

Z twierdzeniem 'im większa liczba krajów w Unii, tym większe bezrobocie' zgodziło się 51\% Austriaków, 47\% Niemców i 46\% Greków. Na pytanie o koszty dla macierzystego kraju w związku z poszerzeniem Unii twierdząco odpowiedziało $62 \%$ Holendrów, 60\% Niemców i 58\% Austriaków. Obywatele Irlandii (68\%), Danii (62\%), Grecji i Finlandii (po 61\%) obawiali się ograniczenia pomocy finansowej w związku z rozszerzeniem, jednak odsetek osób aprobujących akcesję nowych krajów członkowskich był największy właśnie w Danii, Grecji, Holandii, Finlandii i Szwecji. Wyniki aprobaty uzyskane w Belgii, Francji i Luksemburgu były dużo niższe.

Dało się zaobserwować również wyraziste sympatie lub antypatie dla poszczególnych kandydatów. Grecy silnie popierali wejście Cypru do Unii (88\% poparcia), a np. Austriacy i w Niemcy niechętnie widzieli w Unii Rumunię (14\% poparcia w Austrii i 17\% w Niemczech). Również widoczny był spadek poparcia dla przyjęcia takich krajów jak Polska i Węgry9

Społeczeństwa dawnych krajów unijnych najchętniej widziałyby we Wspólnocie Norwegię i Szwajcarię, jako bogate kraje o wysokim poziomie rozwoju cywilizacyjnego, do których nie trzeba będzie dopłacać. Późniejsze badania społeczne dowodziły, że tendencja spadkowa sympatii dla poszerzenia na Wschód się utrzymała. Według badań Eurobarometru nr 59 z wiosny 2003 poparcie dla poszerzenia wśród społeczeństw krajów dawnej unijnej 15-tki wyglądało następująco:

\footnotetext{
${ }^{8}$ Por. www.eurostat.com.

${ }^{9}$ P.W. Walkiewicz, Polska na drodze do Unii Europejskiej. Aspekty negocjacyjne i dostosowawcze, wyd. Rzeszów 2002, s. 57, także szerzej por. How Europeans see themselves: looking through the mirror with public opinion surveys, European Commission, Luxemburg 2001.
} 
Tab. 2. Kraje Unii wobec wschodniego rozszerzenia.

\begin{tabular}{|l|l|l|l|}
\hline Kraj & $\mathbf{Z a}(\%)$ & Przeciw (\%) & Trudno powiedzieć (\%) \\
\hline Szwecja & 56 & 34 & 10 \\
\hline Finlandia & 50 & 40 & 10 \\
\hline Holandia & 48 & 38 & 14 \\
\hline Irlandia & 60 & 19 & 21 \\
\hline Wielka Brytania & 36 & 36 & 28 \\
\hline Dania & 63 & 25 & 12 \\
\hline Belgia & 38 & 44 & 18 \\
\hline Luksemburg & 53 & 40 & 7 \\
\hline Niemcy & 42 & 39 & 19 \\
\hline Austria & 43 & 44 & 13 \\
\hline Francja & 31 & 54 & 15 \\
\hline Hiszpania & 60 & 17 & 23 \\
\hline Portugalia & 60 & 22 & 18 \\
\hline Włochy & 59 & 22 & 19 \\
\hline Grecja & 71 & 19 & 10 \\
\hline
\end{tabular}

Źródło: Eurobarometr nr 59, wiosna 2003.

Wyraźnie widać było znaczący spadek ilości zwolenników wobec poszerzenia Unii na Wschód. W Belgii liczba przeciwników zjednoczenia kontynentu przekroczyła liczbę zwolenników. Podobnie stało się we Francji i Austrii. Duże spadki poparcia wystąpiły również w Finlandii, Holandii i Niemczech. We Francji, kraju o tradycyjne silnych nastrojach antyamerykańskich udział Polski w niepopularnej w Europie wojnie skomentował Jacques Chirac: „te kraje (kraje Europy Wschodniej) straciły szansę siedzenia cicho".${ }^{10}$ Co jakiś czas pojawiały się komentarze prasowe opisujące rosnącą niechęć krajów członkowskich wobec przyjmowania nowych państw: „Witajcie w Unii, jeśli musicie” ${ }^{11}$, „Wejście po przejściach”12, „Ekonomiczny apartheid”, „Żadnych złudzeń”"14.

W 2001 r głośnym echem odbił się raport z badań jakościowych przygotowany przez francuską agencję badawczą OPTE na zlecenie Komisji Europejskiej „Obraz Unii Europejskiej, postaw i oczekiwań społecznych w 15 krajów członkowskich i 10 państwach kandydujących”. Badania odbywały się we współdziałaniu z lokalnymi agencjami badawczymi; ich celem było poznanie wzajemnych sposobów postrzegania się oby-

\footnotetext{
${ }^{10}$ T. Blankley, France blackmails Poland, “The Washington Times” 19.02.2002.

${ }^{11}$ J. Bielecki, A. Stankiewicz, Witajcie w Unii, jeśli musicie, „Rzeczpospolita” 26.04.2002.

${ }^{12}$ K. Bachman, Wejście po przejściach, „Polityka” 20.07.2002.

${ }^{13}$ J. Saryusz Wolski, Ekonomiczny apartheid, „Die Welt” 28.11.2002.

${ }^{14}$ A. Dawidowski, Żadnych złudzeń, „Unia i Polska” 23.10.2000.
} 
wateli w dawnych państwach Unii i krajach kandydackich. Polska część badań zrealizowała agencja Badań Społecznych i Marketingowych BSM, a ich wynik został przedstawiony $\mathrm{m}$.in. $\mathrm{w}$ serwisie informacyjnym PAP. ${ }^{15}$

W raporcie Polacy zostali opisani w sposób, który może być uznany za obraźliwy. Oto zestaw cytatów z tego obszernego 200 stronicowego opracowania:

„Polacy boją się, że na zawsze pozostaną ubogimi krewnymi, nieznanymi i lekceważonymi (s.12). Obawy przeważają nad nadziejami, których z powodu wyjątkowego pesymizmu nie są w stanie wyrazić (s.17).

Polacy uważają się za biedaków, którzy nie maja pełnego prawa wstępu na salony bogatych. Ich słaba znajomość języków obcych ogranicza im możliwość kontaktów. W istocie cechuje ich kompleks niższości związany z negatywnym obrazem Polaków za granicą - oszustów i złodziei (...). Do tego dochodzi żywe poczucie narodowości, które wreszcie po może znaleźć ujście po latach okupacji i zaborów. Ich poczucie godności ma przede wszystkim charakter obronny (s.47).

Dominuje wśród nich obraz Unii gospodarczej, zrzeszającej bogate kraje. Cele, które legły u jej podstaw nie są szerzej znane ani doceniane. Polacy mają skłonność do sprowadzania wszystkiego do kategorii ekonomicznych $(\mathrm{s} .80){ }^{16}$

Późniejsze badania nad wizerunkami krajów i narodów prowadził Instytut Spraw Publicznych w 2003 r. Obejmowały one prawie wszystkie kraje Europy Zachodniej (Austrię, Hiszpanię, Szwecję, Francje, Wielkiej Brytanię i Niemcy). Ich wyniki również pokazały, że w procesie negocjacyjnym Polska i inne kraje Europy Środkowo-Wschodniej nie były traktowane jako równorzędny partner. Większość badanych nie miała również żadnej opinii na temat ówczesnej Polski; dominująca niewiedza dotyczyła wszystkich strategicznych obszarów rozwojowych Polski. Jedynie 15\% obywateli Niemiec, Austrii i Hiszpanii oraz 18\% Francji miało świadomość, że u nas funkcjonuje gospodarka rynkowa, zaś 30\% Niemców i Austriaków oraz 25\% Francuzów uważało, że w Polsce panuje demokracja. 32\% Niemców i Austriaków deklarowało, że uważa nasz system parlamentarny za podobny do tego, który dominuje w Europie Zachodniej. ${ }^{17}$ Obraz Polski jako kraju kandydackiego rysował się jako zgoła odmienny od państw członkowskich UE:

„Państwa Europy Środkowo-Wschodniej postrzegane były w Unii jako odległe geograficznie i cywilizacyjne, odmienne pod względem ekonomicznym i politycznym od dotychczasowych członków. Polska jawiła się jako kraj nie-

\footnotetext{
${ }^{15}$ J. Dessler „Komisja Europejska o przywarach Polaków”, PAP lipiec 2001. <><

${ }^{16}$ „UE-Polak to pazerny fatalista”- serwis informacyjny Wirtualnej Polski z 25.07.2001, szerzej por. E. Skotnicka-Illasiewicz „Swojska kultura lękliwości. O sposobach postrzegania UE przez Polaków i unitów”, Unia i Polska 3.09. 2001.

${ }^{17}$ L. Kolarska-Bobińska „Odmienność oswajana. Obraz Polski w krajach Unii Europejskiej”, wyd. Instytut Spraw Publicznych, Warszawa 2003, s. 9-16
} 
podobny do kraju respondenta: katolicki i tradycyjny, zacofany, o silnej korupcji, nie najlepszej organizacji pracy i gospodarce niepodobnej do gospodarki krajów Unii Europejskiej. (...) Polska w oczach Zachodu wyzwoliła się spod komunizmu, ale jeszcze nie przezwyciężyła politycznych i ekonomicznych konsekwencji tego ustroju. Społeczeństwa zachodnie nie wiedzą jednak, w którym miejscu Polska się znajduje, jak daleko odeszła od komunizmu i kiedy upodobni się do państw Unii Europejskiej”. ${ }^{18}$

Również interesująco pod względem badawczym zapowiada się przyjrzenie się, jak unijni negocjatorzy postrzegali stronę polską w procesie akcesyjnym:

„Dla urzędników Komisji było oczywiste, że to kraje kandydujące są bardziej zainteresowane przystąpieniem do Unii oraz szybkim negocjowaniem umowy. Kraje wschodniego rozszerzenia, w porównaniu nawet do krajów rozszerzenia południowego były postrzegane jako kraje 'bez alternatywy'. (...) Wywoływało to dysonans w konfrontacji z żądaniową postawą przedstawicieli krajów kandydujących: 'Oni mają bardzo wysokie aspiracje, lecz bardzo skromne argumenty po swojej stronie'. (...) W przypadku Polski panowało charakterystyczne przekonanie o 'niekompatybilności jej interesów z Unią'. W przeszłości podobnie była postrzegana Hiszpania. (...) Dla porównania kraje skandynawskie były uznawane za doskonale przygotowane, mające profesjonalną administrację, a przede wszystkim uważane za 'bogatych, dobrze znanych, bliskich przyjaciół'. Kandydaci 'wschodniego rozszerzenia' byli natomiast postrzegani jako biedni, dalecy kuzyni - 'pasażerowie drugiej klasy". ${ }^{19}$

Tak więc w momencie rozszerzenia Unii elity i społeczeństwa Europy Zachodniej postrzegały nas jako kraj zacofany i zapóźniony cywilizacyjnie. Polska to dla większości z nich „terra incognita” i nie było widać specjalnej szansy dla zmiany tego stanu rzeczy. Paradoksalnie, nawet słynni Polacy, którzy budzili dumę narodową w kraju-t.j. Chopin, Maria Skłodowska-Curie, Kopernik nie wszędzie utożsamiani byli z Polską. Dwoje pierwszych wciąż jest uważanych za Francuzów, a trzeci za Niemca ${ }^{20}$. W procesie negocjacyjnym sytuacji Polski zauważalna była pewna ambiwalencja - Polskę uznano za jedno z najważniejszych nowych państw ze względu na jej wielkość, liczbę ludności, położenie geograficzne i tempo rozwoju gospodarczego. Z drugiej zaś strony często wypominano nam, że „Polska była kandydatem balansującym na granicy wypadnięcia z pierwszej fali rozszerzenia, słabo przygotowanym do integracji (np. w porównaniu z Węgrami i Słowenią), mającym poważne opóźnienia w przyjmowaniu acquis communautaire. (...) Pojawiały się mocno akcentowane sugestie, że postawa Polski szkodzi nie tylko jej samej,

\footnotetext{
${ }^{18}$ L. Kolarska-Bobińska „Odmienność oswajana. Obraz Polski ....”, op.cit.

${ }^{19}$ Wypowiedzi urzędników Komisji w wywiadach dla: Victor Martinez Reyes „Reguły gry, czyli o negocjacjach akcesyjnych i łączeniu się Europy”, Wyd. Naukowe Scholar Warszawa 2000, s. 213-214.

${ }^{20}$ A. Grzeszak „Poland-gdzie to jest? Przymiarka do marki”, Polityka 25.05.2002.
} 
ale też innym krajom kandydującym”. ${ }^{21}$ Po rozpoczęciu wojny w Iraku do narodowych wad dołączyła 'podwójna lojalność', jaką wykazaliśmy wobec rządów państw Europy Zachodniej. Pojawiły się głosy o polskim 'ślepym proamerykanizmie' i o polskim 'ośle trojańskim’. Gdyby o wejściu do Unii decydowały referenda i poparcie społeczeństw państw członkowskich, nasze przystąpienie do Wspólnot byłoby bardzo mało prawdopodobne.

\section{Obraz Polski i Polaków w dawnych krajach Unii w okresie poakcesyjnym- początkowe sukcesy Polski}

Dziś, ponad dekadę od przystąpienia naszego kraju do struktur europejskich należy zadać sobie to samo pytanie - jak jest postrzegana Polska dzisiaj? Czy jej wizerunek uległ znaczącym zmianom, czy uległ poprawie, a jeśli tak to w jakim zakresie?

Otóż na początek należałoby powiedzieć, że sama akcesja Polski i krajów Wyszehradzkich do struktur unijnych automatycznie przekłada się na poprawę wizerunku, gdyż oznacza „formalne uznanie przez inne państwa członkowskie, że Polska spełniła kryteria kopenhaskie, czyli jest państwem zbudowanym na zasadach rządów prawa, poszanowanie praw mniejszości oraz gospodarki rynkowej”. ${ }^{22}$

Mimo że nie jest to powszechnie znane ani polskiej, ani zagranicznej opinii publicznej Polska awansuje w rankingach gospodarczych i w rankingach najsilniejszych marek państw. Według raportu Country Brand Index autorstwa agencji Futurebrand Polska w 2011 roku awansowała o 3 miejsca w rankingu - wtedy na 113 krajów zajmowaliśmy 79 pozycję. Ale już rok później, w sierpniu 2012 r. według agencji Brand Finance, szacującej wartość marek państw na świecie 'marka narodowa Polski odnotowała największy spektakularny wzrost wartości i po raz pierwszy w historii rankingu znalazł się w czołowej dwudziestce najcenniejszych marek świata. ${ }^{23}$ Polska awansowała z 24 pozycji na 20. miejsce i po raz pierwszy wartość marki Polska została wyceniona na 472 mld dolarów. Ze wszystkich badanych krajów i ich marek wartość marki Polska osiągnęła najwyższy skok - aż o 75\%. Według autorów badania Polska osiągnęła te wartości dzięki przewidywanym $3 \% \mathrm{PKB}$, co uważane jest za szczególnie dynamiczne.

Kolejny sukces odniosła Polska również w najnowszym rankingu „Doing Business 2017” Banku Światowego. Na 190 ocenianych krajów odnieśliśmy 24. miejsce - był to skok o jedną pozycję w stosunku do roku 2016. Awans ten zawdzięczamy głównie dzięki reformie prawa podatkowego, restrukturyzacyjnego i upadłościowego, co przyczyniło się do znaczącej poprawy sytuacji przedsiębiorców w naszym kraju. Wyprzedziliśmy większość krajów naszego regionu: Czechy zajęły 27. miejsce, Słowacja miejsce 33., Rumunia 36., Bułgaria 39. oraz Węgry 41. Przed nami uplasowały się tylko państwa bałtyckie-Estonia z 12. miejsca awansowała na 10., Łotwa zajęła 14. i Litwa $21 .^{24}$

\footnotetext{
${ }^{21}$ M. Warchala (red). „Wizerunek Polski w prasie krajów Unii Europejskiej”, wyd. Instytut Spraw Publicznych, Warszawa 2002.

${ }^{22}$ J. Fomina, J.Frelak „Wizerunek Polski i Polaków w Wielkiej Brytanir”, wyd. ISP 2011, s.11.

${ }^{23}$ K. Niklewicz „Przewodnictwo Polski w Radzie Unii Europejskiej”, 2013, s.261-262.

${ }^{24} \mathrm{http} / / /$ www.doingbusiness.org/reports/global-reports/doing-business-2017.
} 


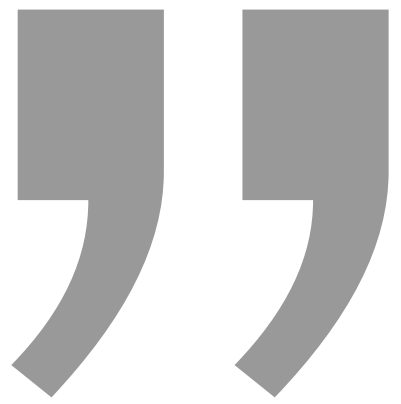

Społeczeństwo polskie jest uważane za jedno z najmłodszych na kontynencie, co w obliczu kryzysu demograficznego u starzejących się społeczeństw Europy Zachodniej i pojawiających się tam problemów z zachwianiem równowagi liczebnej między pokoleniami, niską wydolnością systemów emerytalnych i koniecznością importowania sity roboczej w przyszłości, ukazuje Polskę jako kraj nowych możliwości.

Coraz częściej zaczyna się postrzegać Polskę jako kraj nowych szans, gdzie wzrost gospodarczy osiaga ponad 3\% PKB rocznie. W momencie akcesji do Unii Europejskiej wartość nominalna PKB w Polsce wynosiła 883,7 miliarda złotych, natomiast 10 lat później było to już 1 635,7 miliarda złotych, czyli prawie 2x więcej. Z kolei PKB per capita w 2004 roku wynosił 50,5 \% średniej UE, po 10 latach przekroczył 66,8 \% średniej Unii Europejskiej. Przewiduje się, że jeśli uda się utrzymać się zbliżony poziom wzrostu gospodarczego to w 2025 roku PKB per capita w Polsce osiągnie wartość 70\% średniej państw dawnej „UE- 15”25.

Wartość inwestycji zagranicznych w Polsce wykazuje tendencje rosnące, co dowodzi wzrastającego zaufania u zachodnich przedsiębiorców do naszego kraju. Dzięki dotacjom unijnym rozwijają się również polskie miasta. Społeczeństwo polskie jest uważane za jedno z najmłodszych na kontynencie, co w obliczu kryzysu demograficznego u starzejących się społeczeństw Europy Zachodniej i pojawiających się tam problemów z zachwianiem równowagi liczebnej między pokoleniami, niską wydolnością systemów emerytalnych i koniecznością importowania siły roboczej w przyszłości, ukazuje Polskę jako kraj nowych możliwości.

Również polscy przedsiębiorcy coraz śmielej zaczynają zdobywać rynki zagraniczne. Liderem wśród polskich firm jest tu KGHM Polska Miedź SA; w coraz większej ilości krajów hasło „made in Poland” zaczyna kojarzyć się coraz lepiej. I tak polskie autobusy marki Solaris jeżdżą po drogach Norwegii, Niemiec, Austrii i Włoch. Bydgoska Pesa produkuje pociągi, które jeżdżą nie tylko w Polsce, ale również w Rosji, Czechach, Niemczech i Włoszech. Polskie okna firm Fakro, Drutex i Oknoplast znajdują nabywców na Ukrainie, Węgrzech, w Niemczech, Wielkiej Brytanii, Francji, USA, Austrii, Szwajcarii, także w Australii i na Bliskim Wschodzie. Firma Ursus eksportuje swoje

\footnotetext{
${ }^{25} \mathrm{http} / /$ www.bankier.pl/wiadomosc/PKB-na-osobe-w-Polsce-goni-srednia-UE-Mocny-wzrost-do-2018-roku7255686.html
} 
traktory na rynek afrykański, a Inglot nabywców swoich kosmetyków poza Europą Zachodnią i USA znalazł również na Filipinach, w Indiach, w państwach arabskich i w południowej Afryce. Firma CD Project reklamowała się na Times Square w Nowym Yorku; grę „Wiedźmin” sprzedała w liczbie $16 \mathrm{mln}$ egzemplarzy na całym świecie. Coraz bardziej popularna na świecie staje się firma Audioteka z oryginalnym systemem sprzedaży swoich audiobooków. ${ }^{26}$

Do tego coraz popularniejsze stają się polskie marki premium. Jachty firm Sunreef, Galeon i Delphia w 90\% sprzedają się na eksport na całym świecie. Za produktu o wysokim prestiżu uważa się polskie wódki tj. Belvedere i Chopin. Firma Irena Eris jest obecna w Niemczech i Wlk. Brytanii (jej produkty można kupić w londyńskim Harrodsie); we Francji zaistniała w prestiżowym gronie Comite Colbert. Wysoko punktowane stają się polskie hotele i turystyka SPA. Polscy przedsiębiorcy coraz mocniej zaznaczają swoją obecność również w segmencie marek luksusowych.

Rok temu Polska znalazła się również w gronie 20 najczęściej odwiedzanych państw na świecie. Od 2000 r przyjechało do Polski 220 mln turystów, co w 2015 roku uczyniło Polskę 18 najbardziej popularnym turystycznie państwem na świecie i $11 \mathrm{w}$ Europie. ${ }^{27} 1$ listopada 2015 roku specjaliści z Lonely Travel zaliczyli nasz kraj do grupy 10 krajów na świecie i tylko 2 w Europie, które zostały wyróżnione tytułem „Best in Travel 2016 ”. ${ }^{28}$ Miasta polskie na które eksperci z Lonely Travel zwrócili uwagę to: Wrocław jako Europejska Stolica Kultury 2016 r., Kraków jako miejsce Światowych Dni Młodzieży w 2016 r., poza tym: Łódź, Szczecin, Gdańsk; za interesujący region zostały również uznane Mazury i Puszcza Białowieska. Według szacunków POT w 2014 roku do Polski przyjechało $16 \mathrm{mln}$ turystów, co oznaczało $1 \mathrm{mln}$ więcej niż w roku 2012. Najwięcej turystów przyjeżdża do nas z Republiki Federalnej Niemiec, Czech, Ukrainy, Słowacji, ale także Wielkiej Brytanii i Holandii. Obecnie w Polsce wpływy z turystyki sięgają rocznie 5\% PKB.

Również wybór Donalda Tuska na przewodniczącego Rady Unii Europejskiej, a Elżbiety Bieńkowskiej na Europejskiego Komisarza ds. Rynku Wewnętrznego i Usług bez względu na komentarze w kraju początkowo postrzegany był jako sukces Polski. Wśród opinii zagranicznych przeważało podejście, że nie jest to równoznaczne z osiągnięciem przez Polskę statusu równoprawnego z pozostałymi krajami UE-15, ale pozycji międzynarodowej, która wcześniej była dla Polski zupełnie niedostępna.

\section{Polska ponad 10 lat po akcesji do UE - wyniki badań polskiej i międzynarodowej opinii publicznej}

Badania opinii publicznej prowadzone w krajach Zachodniej Europy pokazuja jednak, że Polska wciąż postrzegana jest jako jeden z najbiedniejszych krajów Europy. Podobnie pokazywana jest dziś Grecja. Badania „European perception of life in

\footnotetext{
${ }^{26} \mathrm{http}: / /$ www.polandgoglobal.pl

${ }^{27}$ http://wyborcza.biz/biznes/1,100896,19329021,polska-w-pierwszej-dwudziestce-najchetniejodwiedzanych-krajow.html

${ }^{28} \mathrm{http}$ ///www.pot.gov.pl/nowosci/l/wiadomosci/wiadomosci-z-pot/nagrody-best-in-travel-2016-rozdanepolska-w-czolowce-swiatowych-destynacji-turystycznych
} 
other countries ${ }^{29}$ przeprowadzone w marcu 2016 roku przez Livewhat, agencję afiliowaną przy Institute of Citizenship Studies (InCite) na Uniwersytecie w Genewie pokazują, że jedynie $25 \%$ respondentów z badanych krajów uważało, że warunki życia w Polsce są dobre. Również większość badanych oceniła, że życie w Polsce (i również Grecji) ,jest mniej szczęśliwe niż jest w rzeczywistości", podczas gdy Polacy posiadają bardziej przychylny obraz swoich sąsiadów. Dla porównania najlepsze oceny u wszystkich badanych zebrała Szwajcaria i Szwecja, wysoko notowane są również Niemcy. Grecja wypadła najgorzej w zestawieniu- w większości badanych krajów tylko $10 \%$ respondentów uważa, że warunki życia w tym kraju są wystarczające. Kraje południa Europy, tj. Hiszpania i Włochy wypadają nieznacznie lepiej niż Polska. Co ciekawe większość obywateli badanych krajów czyli Francji, Niemiec, Włoch, Szwecji, Szwajcarii deklaruje, że życie w kraju sąsiada jest lepsze niż w ich kraju macierzystym (tab.3).

Tab.3. Postrzeganie przez mieszkańców Europy warunków życia w różnych krajach

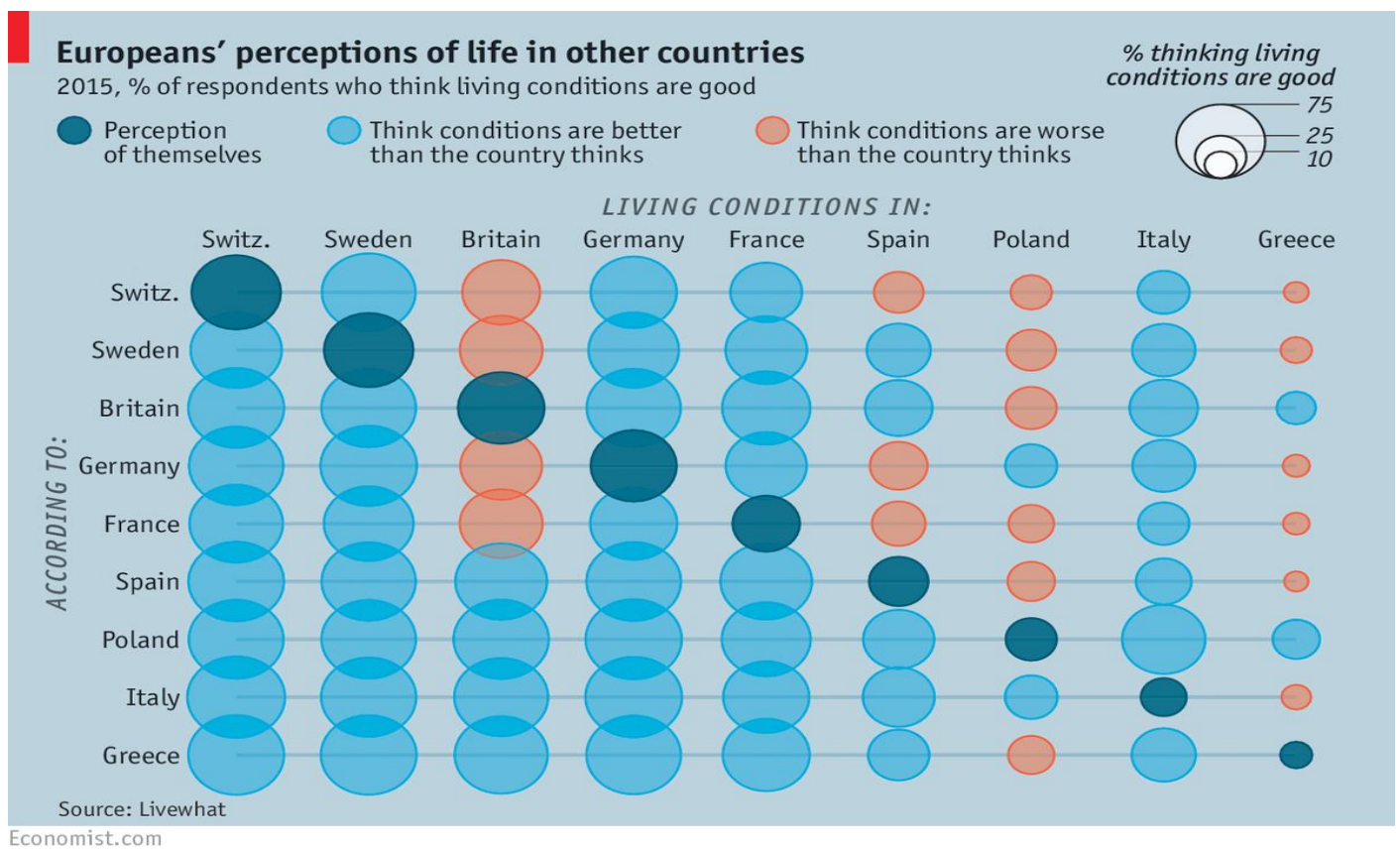

Źródło: Livewhat, Geneva-based survey, The Economist 29.03.2016.

Symptomatyczne jest, że poparcie dla procesu dalszego rozszerzenia UE w krajach dawnej UE-15 utrzymuje się na niskim poziomie. Najnowsze badania Eurobarometru z listopada 2016 r. pokazują, że poparcie dla dalszego rozszerzania Unii w krajach za-

${ }^{29}$ Livewhat, Geneva-based survey, cyt. za: “Green-eyed continent”, The Economist 29.03.2016. 
łożycielskich jest nadal niewielkie. 71\% Austriaków, 68\% Niemców i 65\% obywateli Francji i Luksemburga opowiada się przeciwko temu procesowi. Obywatele UE, którzy wykazują wysoki poziom poparcia dla rozszerzania UE należą najczęściej do grupy krajów niedawno przyjętych, tj.: Litwa (65\% pozytywnych wskazań), Chorwacja (62\%), Rumunia $(61 \%) .^{30}$ (tab.4).

\section{Tab.4. Poparcie dla dalszego rozszerzenia w krajach Unii Europejskiej}

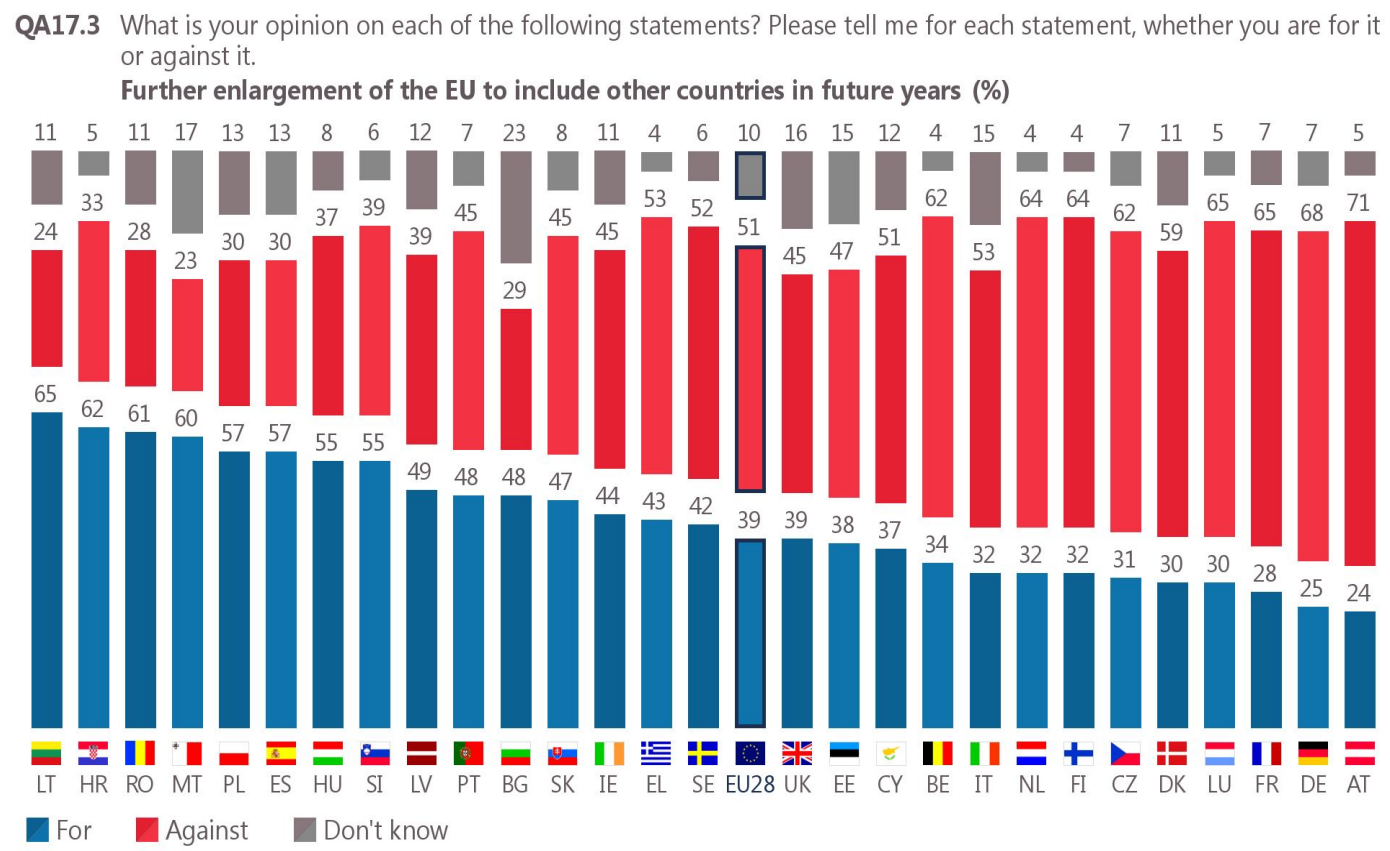

Źródło: Standard Eurobarometr nr 86, listopad 2016.

Badania wizerunkowe, realizowane przez Pew Research Center z kolei dotykają delikatniejszej materii- wzajemnych stereotypów narodowych. ${ }^{31}$ W badaniu PEW z 2013 r. jako naród „najbardziej godny zaufania” uznani zostali Niemcy, co nie przeszkodziło respondentom wytypować ich jako również „najbardziej aroganckich” i „najmniej współczujących” (wskazania większości respondentów). Polacy w tym zestawieniu zostali wskazani jako „najmniej aroganccy” i „najbardziej współczujący” jedynie przez swoich rodaków, natomiast pozostali badani w tych kategoriach nie wymienili Polaków (tab.5).

\footnotetext{
${ }^{30}$ Standard Eurobarometr nr 86, Europeans' opinion of the EU's priorities, listopad 2016:

http://ec.europa.eu/COMMFrontOffice/publicopinion/index.cfm/Survey/getSurveyDetail/instruments/S TANDARD/surveyKy/2137, s.22.

${ }^{31} \mathrm{https} / /$ richardbrenneman.wordpress.com/2013/05/14/chart-of-the-day-how-europeans-see-each-other/
} 
Tab.5. Tworzenie stereotypów w Europie

\begin{tabular}{|c|c|c|c|c|c|c|}
\hline \multirow[b]{2}{*}{ Views in: } & \multirow[b]{2}{*}{$\begin{array}{c}\text { Most } \\
\text { Trustworthy } \\
\text { Germany }\end{array}$} & $\begin{array}{r}\text { Stereo } \\
\text { Trustworth } \\
E U\end{array}$ & $\begin{array}{l}\text { typing i } \\
\text { y, Arroga } \\
\text { nation most }\end{array}$ & $\begin{array}{l}\text { in Europ } \\
\text { nt and Co } \\
\text { likely to be }\end{array}$ & $\begin{array}{l}\text { me } \\
\text { massionate } \\
\text { named... }\end{array}$ & \multirow[b]{2}{*}{$\begin{array}{c}\text { Least } \\
\text { Compassionate } \\
\text { Germany }\end{array}$} \\
\hline & & $\begin{array}{l}\text { Least } \\
\text { Trustworthy } \\
\text { France }\end{array}$ & $\begin{array}{l}\text { Most } \\
\text { Arrogant } \\
\text { France }\end{array}$ & $\begin{array}{c}\text { Least } \\
\text { Arrogant } \\
\text { Britain }\end{array}$ & $\begin{array}{c}\text { Most } \\
\text { Compassionate } \\
\text { Britain }\end{array}$ & \\
\hline France & Germany & Greece & France & France & France & Britain \\
\hline Germany & Germany & Greece/Italy & France & Germany & Germany & Britain \\
\hline Italy & Germany & Italy & Germany & Spain & Italy & Germany \\
\hline Spain & Germany & Italy & Germany & Spain & Spain & Germany \\
\hline Greece & Greece & Germany & Germany & Greece & Greece & Germany \\
\hline Poland & Germany & Germany & Germany & Poland & Poland & Germany \\
\hline Czech Rep. & Germany & Greece & Germany & Slovakia & Czech Rep. & Germany \\
\hline
\end{tabular}

Źródło: PEW, maj 2013.

Niemcy wskazywani są jako „najciężej pracujący” i „najmniej skorumpowani” we wszystkich zestawieniach. Najgorszą opinią cieszą się Grecy. W niechlubnym rankingu narodów „najmniej pracowitych” i „najbardziej skorumpowanych” (tab.6) zwyciężają najczęściej narody południa Europy, tj. Włosi, Hiszpanie i Grecy. ${ }^{32}$ Żaden badany naród nie wymienił w tych wskazaniach Polaków, co może napawać optymizmem, gdyż wysoki poziom korupcji był jedną z negatywnych cech, jaką zarzucano nam w momencie akcesji do UE.

Tab.6. Tworzenie stereotypów w Europie

\begin{tabular}{|c|c|c|c|c|}
\hline \multicolumn{5}{|c|}{ Stereotyping in Europe } \\
\hline \multicolumn{5}{|c|}{$\begin{array}{l}\text { Who Works Hardest, Who's Corrupt } \\
\text { EU nation most offered as top choice as... }\end{array}$} \\
\hline Views in: & $\begin{array}{c}\text { Most } \\
\text { Hardworking }\end{array}$ & $\begin{array}{c}\text { Least } \\
\text { Hardworking }\end{array}$ & $\begin{array}{l}\text { Most } \\
\text { Corrupt }\end{array}$ & $\begin{array}{c}\text { Least } \\
\text { Corrupt }\end{array}$ \\
\hline Britain & Germany & Greece & Italy & Germany \\
\hline France & Germany & Italy & Italy & Germany \\
\hline Germany & Germany & Greece & Italy & Germany \\
\hline Spain & Germany & Greece & Spain/Italy & Germany \\
\hline Italy & Germany & Romania & Italy & Germany \\
\hline Greece & Greece & Italy & Greece & Germany \\
\hline Poland & Germany & Greece & Poland & Germany \\
\hline Czech Rep. & Germany & Greece & Czech Rep. & Germany \\
\hline
\end{tabular}

Źródło: Pew 2012, The Economist 4.06.2012

${ }^{32}$ A. Santoso „Greek Think They're the Hardest Working People in Europe”, The Economist 4.06.2012. 

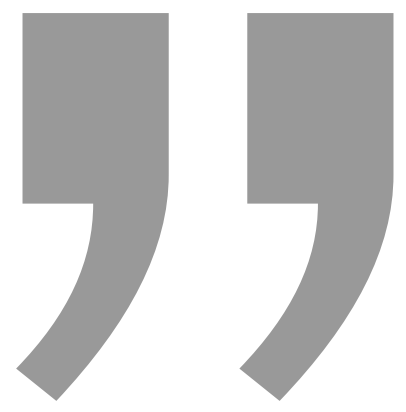

\section{Trudno oprzeć się wrażeniu, że obraz Polski} wyłaniający się z polskich badań opinii i opracowań naukowych publikowanych w Polsce jest lepszy niż ten wyłaniający się z raportów, czy statystyk zachodnich. U nas akcentuje się dynamikę pozytywnych zmian, zmniejszający się dystans do krajów rozwiniętych, progres jakiego udało nam się dokonać przez ostatni czas; w opracowaniach i tekstach publikowanych w państwach zachodnich akcentowane są przede wszystkim niechęć do dalszego rozszerzania u społeczeństw zachodnich, zagrożenia powstałe na rynku pracy związane
z falami migracji czy negatywny obraz rozszerzania wschodniego.

Brak konkretnych wskazań w badaniach PEW dla Polski wynika być może z tego, że Polska w tamtym czasie - jak podkreślali eksperci - jeśli chodzi wizerunek ogólny była „krajem bez twarzy”" ${ }^{33}$ tzn. nie miała wyraźnego wizerunku na arenie międzynarodowej. Z badań OBOP dla MSZ wynikało, że wizerunek Polski i Polaków na zachodzie był niespójny- z jednej strony uważano, że wizerunek naszego kraju jest nijaki, $z$ drugiej podkreślano, że „wizerunek polskich obywateli jest w ogromnej większości przypadków lepszy i bardziej wyrazisty niż wizerunek całego kraju". ${ }^{34}$

Niestety, nie oznacza to, że we wszystkich krajach wizerunek Polaków jest taki sam i tak z badań TNS OBOP z 2013 r. wynika, że narody, które wykazują najwięcej symptomów sympatii w kierunku naszego kraju to Portugalczycy, Hiszpanie, Francuzi oraz Ukraińcy. Z kolei najmniej zwolenników mamy w Holandii, Austrii i Niemczech, co jest bardzo charakterystyczne, gdyż Holandia i Niemcy, jak również Wielka Brytania są to najbardziej popularne destynacje, do jakich migrują Polacy po 2004 r. ${ }^{35}$ Dość oczywista może się także wy-

\footnotetext{
${ }^{33}$ W. Smoczyński „Polska - kraj bez twarzy”, Polityka 30.06. 2009, Marketingowa Strategia Polski w sektorze turystyki na lata 2008-2015; Analiza wyników badań wizerunku Polski i postrzegania polskiej marki na świecie 2008.

${ }^{34}$ Badanie opinii „Określenie wizerunku, który Polska powinna promować z granicą”, Laboratorium Badan Społecznych dla MSZ, Warszawa listopad 2013, s.18.

${ }^{35}$ Według danych GUS pod koniec roku 2015 poza granicami Polski przebywało $2 \mathrm{mln} 397$ tys. obywateli
} 
dawać konstatacja, że zachodni Europejczycy postrzegają nas jako Wschód Europy, a dla mieszkańców Wschodu Europy -jak np. dla Ukraińców „Polska to już Zachód” ${ }^{36}$

Warto przyjrzeć się wynikom badań nad obrazem Polski w wybranych krajach UE. Cykliczne badania nad wzajemnymi wizerunkami Polaków i Niemców, tzw. „Barometr Polska - Niemcy” prowadzi Instytut Spraw Publicznych. Badania ISP pokazują, że w Niemczech w postrzeganiu Polski zarysowuje się pewna dwoistość ${ }^{37} \mathrm{Z}$ jednej strony Polska kojarzona była jeszcze niedawno z trudną sytuacją gospodarczą, która wypycha swoich obywateli do niskokwalifikowanych prac sezonowych; słynne określenie „Polnische wirtschaft" było symbolem skrajnej niegospodarności i bałaganu. W niektórych kręgach społecznych, zwłaszcza przy terenach przygranicznych obecny był żywy stereotyp Polaka jako złodzieja samochodó $w^{38}$ i obraz Polski jako kraju o wysokiej przestępczości. Z drugiej strony - Polska coraz częściej jest postrzegana przez pryzmat dynamicznych zmian gospodarczych, licznych inwestycji infrastrukturalnych i wzajemnych kontaktów biznesowych. W 2016 r. wartość polsko - niemieckiej wymiany gospodarczej przekroczyła 100 mld euro (wzrost o 22 mld od roku 2013) ${ }^{39}$, co sprawia, Polska staje się jednym z ważniejszych partnerów handlowych dla Niemiec. Nie pozostaje to bez wpływu na wzajemne postrzeganie się obu narodów. I tak, pomimo że Niemcy deklarowali, że nie uważają, że Polacy jako ludzie są do nich podobni - w ich opinii daleko bliżej było nam do Rosjan ${ }^{40}$, tak w badaniach późniejszych twierdzili, że byliby w stanie zaakceptować Polaka jako kolegę z pracy (79\% pozytywnych wskazań), również jako obywatela swojego kraju (62\% odpowiedzi na tak), a także jako zięcia (49\%). ${ }^{41}$ Wynika z tego, że poziom społecznej akceptacji Niemców dla Polaków wykazuje tendencje rosnące.

W Belgii również panuje dwoistość w postrzeganiu naszego kraju i obywateli z jednej strony dominuje stereotypowy obraz Polaka: słabo wykształconego, pracującego na czarno emigranta w niskokwalifikowanej pracy, nierzadko nadużywającego alkoholu. Polska postrzegana jest jako kraj wolno rozwijający się, o zimnym klimacie; kojarzący się z trudną historią (II wojna światowa, lata komunizmu). Z drugiej strony - w opiniach międzynarodowej populacji urzędników obraz Polski jest zgoła inny - cechy, jakie się

naszego kraju, szacowanych łącznie jako liczba migrantów tymczasowych i osób, które na stale osiedliły się poza Polską. I tak w Wielkiej Brytanii w 2015 r. przebywało 720 tys. Polaków (według nieoficjalnych danych ponad 100000), w Niemczech 655 tys., w Holandii 112 tys., w Irlandii 111 tys. Liczba polskich emigrantów wzrosła o 82 tys. w stosunku do poprzedniego roku.

${ }^{36}$ Badanie opinii „Określenie wizerunku...”, Laboratorium Badan Społecznych dla MSZ, Warszawa, listopad 2013, s. 20.

37 „Barometr Polska-Niemcy”, Instytut Spraw Publicznych, jesień 2013.

${ }^{38}$ Za czasów komunizmu zostały ukute nawet powiedzenia: „Fast gestohlen, schon in Polen” i „Fahren sie nach Polen, ihre Auto ist schon da”, czyli: „Dopiero co ukradzione, jest już w Polsce”, „Proszę jechać do Polski, pana auto już tam jest”.

${ }^{39}$ Por.: https://www.obserwatorfinansowy.pl/tematyka/makroekonomia/wymiana-handlowa-miedzypolska-a-niemcami-na-rekordowym-poziomie/

${ }^{40}$ Szerzej por.: „Barometr Polska-Niemcy”, Instytut Spraw Publicznych, jesień 2013.

${ }^{41}$ Szerzej por.: „Barometr Polska-Niemcy”, op.cit. 
przypisuje Polakom to: „ambicja, odwaga, przebojowość, młodość, dynamizm”42, akcentowany jest rzeczywisty potencjał i dynamika zmian naszego kraju.

Ciekawie prezentuje się wizerunek Polaków w Wielkiej Brytanii. W ciągu ostatnich 10 lat nastąpiła pozytywna zmiana wizerunkowa w postrzeganiu Polski. Społeczeństwo brytyjskie w większości ma świadomość, że Polska jest krajem demokratycznym, w którym dominuje demokracja parlamentarna i gospodarka rynkowa. 60\% badanych twierdzi, że miało kontakty z Polską, czy Polakami i uważa ich za godnych zaufania - zaakceptowaliby ich w roli turysty, sąsiada, czy członka rodziny. Pomimo, że jedynie 6\% Brytyjczyków przebywało w Polsce z wizytą, ponad połowa Brytyjczyków uważa, że Polacy są do nich podobni. Wizerunek Polaków w Wielkiej Brytanii nie jest jednak wolny od obciążeń - Brytyjczycy wciąż postrzegają Polskę jako kraj biedny, zacofany, dotknięty korupcją i biurokracją; co ciekawe jako mniejszy i mniej zaludniony niż w rzeczywistości. ${ }^{43}$ Uważają, że polska emigracja przyczyniła się do zbytniego obciążenia brytyjskiego systemu opieki społecznej i przyczyniła się do wzrostu bezrobocia w niektórych grupach zawodowych, co może powodować napięcia społeczne. Pomimo jednak, że wciąż trwają negocjacje nad warunkami wystąpienia Wielkiej Brytanii z UE (napięcia związane z Brexitem), jak również nad ograniczeniem profitów brytyjskiego systemu socjalnego dla imigrantów z UE można powiedzieć, że Polacy cieszą się w UK pewną sympatią. Pracują tam coraz częściej w wyuczonych zawodach jako lekarze, pielęgniarki, inżynierowie, czy pomocnicy biurowi; nie tylko pracownicy fizyczni. Ich praca, bez względu na to jak kwalifikowana cieszy się wśród brytyjskich pracodawców uznaniem. „You are Britan’s favourite migrants”- miał powiedzieć do Polaków brytyjski poseł konserwatywny Greg Hands. ${ }^{44}$ Podobne opinie można znaleźć wśród Polaków mieszkających w Wielkiej Brytanii. Dominika Swieżewska pisze:

”Nasza pracowitość i wykształcenie oraz chęć integracji powoduje, że wize-
runek Polaka staje się coraz bardziej pozytywny. Świadczy o tym choćby za-
potrzebowanie na polskich fachowców w polskiej gospodarce. Powstają rów-
nież dokumenty i instytucje mające ułatwić Polakom integrację i życie na
Wyspach. Banki udzielają kredytów, Polki rodzą dzieci, Polacy inwestują
w nieruchomości, kursy dokształcające. Badania wskazują, że Polacy wciąź
czują się w Wielkiej Brytanii raczej jako goście niż równoprawni mieszkań-
cy. Wszystko jednak przemawia za tym, że o ile wciąż będziemy pracować
nad naszym pozytywnym wizerunkiem, o tyle z czasem poczujemy się na
emigracji bardziej jak u siebie bardziej jak w domu”.

\footnotetext{
${ }^{42}$ Badanie opinii „Określenie wizerunku...”, Laboratorium Badań Społecznych dla MSZ, Warszawa, listopad 2013, s.18.

${ }^{43}$ Badanie opinii „Określenie wizerunku...”, Laboratorium Badań Społecznych dla MSZ, Warszawa, listopad 2013, s.18.

${ }^{44}$ M.P. Garapich „Migracje, społeczeństwo obywatelskie i władza. Uwarunkowania stowarzyszeniowości etnicznej i rozwoju społeczeństwa obywatelskiego wśród polskich emigrantów w Wielkiej Brytanii, w: Fomina, Frelak, art. cyt. s. 14.

${ }^{45}$ Dominika Swieżewska ,Jak postrzegają nas Brytyjczycy, czyli wizerunek Polaka na Wyspach”w: http://polemi.co.uk/lajt/artykuly/wizerunek-polakow-w-wielkiej-brytanii-5511, www.kobietawuk.info.
} 
Trudno nie zauważyć, że właśnie migranci staja się wizytówką naszego kraju za granicą i od nich również zależały będą zmiany w postrzeganiu Polski. Warto jeszcze raz podkreślić, że obywatele naszego kraju cieszą się większą sympatią i lepszym wizerunkiem niż samo państwo polskie, które lepiej i bardziej prawdziwe prezentuje się wśród elit europejskich niż wśród zwykłych ludzi.

Trudno oprzeć się wrażeniu, że obraz Polski wyłaniający się z polskich badań opinii i opracowań naukowych publikowanych w Polsce jest lepszy niż ten wyłaniający się z raportów, czy statystyk zachodnich. U nas akcentuje się dynamikę pozytywnych zmian, zmniejszający się dystans do krajów rozwiniętych, progres jakiego udało nam się dokonać przez ostatni czas ${ }^{46}$; w opracowaniach i tekstach publikowanych w państwach zachodnich akcentowane są przede wszystkim niechęć do dalszego rozszerzania u społeczeństw zachodnich ${ }^{47}$, zagrożenia powstałe na rynku pracy związane z falami migracji czy negatywny obraz rozszerzania wschodniego. ${ }^{48}$ Zauważane są również deficyty i mankamenty krajów należących do New Members States. ${ }^{49}$ Adam Balzer z demosEuropa relacje Polski i UE trafnie określił jako „miłość platoniczną". ${ }^{50}$

\section{„Polska jako nowy ból głowy Europy”. Polska i Polacy w wybranych materiałach z prasy zachodniej}

Na szczególną uwagę zasługuje czas po wyborach parlamentarnych z 25 X 2015 r., kiedy przez media zachodnie przetoczyła się lawina tekstów przedstawiających Polskę w negatywnym świetle. Wygraną Prawa i Sprawiedliwości korespondenci prasy zagranicznej skomentowali jako wybór „Polski zaściankowej, ksenofobicznej, wręcz radykalnej”. Oto niektóre fragmenty ich publicystyki: „Polska obrała niebezpieczny kurs w kierunku autorytaryzmu" 51 , "Polska zmierza ku autorytaryzmowi w stylu Orbána"52, Polska przywraca „sowiecki model cenzury, którym (...) świat powinien się poważnie zaniepokoić". ${ }^{53}$ Na uwagę zasługują także następujące teksty: "Retoryka drutu kolczaste-

\footnotetext{
${ }^{46}$ „Barometr Polska-Niemcy”, Instytut Spraw Publicznych, jesień 2013, Badanie opinii „Określenie wizerunku...”, Laboratorium Badań Społecznych dla MSZ, Warszawa, listopad 2013.

${ }^{47}$ Np. Standard Eurobarometr nr 86, listopad 2016.

${ }^{48}$ U. Sedelmeier „Europe after the Eastern Enlargement of the European Union: 2004-2014”, Heinrich Boell Stiftung, w: http://aiv-advies.nl/download/1b2da592-0f83-4791-b83f-fe822471ff84.pdf, I. Bond " $E U$ Enlargement', Center for European Reform, www.cer.org.uk.

49 "The EU Capacity for Futher Enlargeement" nr 71, Advisory Council on International Affairs $2010 \mathrm{w}$ : http://aiv-advies.nl/download/1b2da592-0f83-4791-b83f-fe822471ff84.pdfs, I. Bond "EU Enlargement", Center for European Reform, www.cer.org.uk.;

http://www.cer.eu/sites/default/files/publications/attachments/pdf/2014/bal_comp_ib_eu_enlargement july2014-9463.pdf

${ }^{50}$ A. Balzer ,Just A Platonic Love?- Poland and the EU Enlargement" w: "Poland and the Czech Republic: Advocates of the EU Enlargement?' wyd. Demos EUROPA Center for European Strategy Warszawa 2010.

${ }^{51} \mathrm{~J}$. Diehl "Poland's disturbing tilt to the right", The Washington Post 29.11.2015.

${ }^{52}$ F. Zakaria, CNN o Polsce, CNN, 6.12.2015.

${ }^{53}$ F. Zakaria, op.cit.
} 
go" ${ }^{54}$, „Polska jako nowy ból głowy Europy” ${ }^{55}$, „Polska - nowy rząd już po dwóch tygodniach denerwuje Europę". ${ }^{56}$ Ze względu na duży komponent emocjonalny zawarty w tych tekstach, należy im się osobna analiza.

I tak w artykule „Polska jako nowy ból głowy Europy”- „Europe’s new headache” możemy przeczytać, że:

„Kiedy PIS było ostatni raz u władzy, jego rządy cechowały nieodpowiedzialne posunięcia i nacjonalistyczna paranoja. Wydaje się, że mimo upływu czasu nic się nie zmieniło. Podczas swoich poprzednich rządów w latach 20052007, PIS wdawało się w bójki z Niemcami i stworzyło atmosferę histerycznej nieprzewidywalności. (...) Polska była okrętem flagowym ekspansji na wschód, dowodem, że demokrację i rządy prawa można eksportować. Jeśli PIS chce skończyć te erę, jest na najlepszej drodze. (....) Ten zwrot ku populizmowi zaszkodzi Polsce. Ale większym zmartwieniem jest to, że może tez sparaliżować Unię w najważniejszych dla niej problemach, a zwłaszcza w sprawie kryzysu uchodźczego"57.

Również niemieckie media wykazują zaskakującą zbieżność narracji. „Suddeutsche Zeitung" pisze:

„Nowy polski rząd, kierowany przez swojego spiritus rector Jarosława Kaczyńskiego, natychmiast rozpoczął przebudowę Polski w państwo, w którym władza przestała być podzielona i kontrolowana, lecz została całkowicie skupiona w rękach Kaczyńskiego i jego nacjonalistycznej partii PIS."

„Die Welt” ostrzega:

„W Polsce grozi ni mniej nie więcej jak dyktatura, tym razem nie komunistyczna, lecz narodowo-konserwatywna. To bardzo źle dla Polski, a w dodatku jest to naigrywaniem się z odwagi i ofiarności ludzi, którzy walczyli i zginęli w walce o Polską demokrację". ${ }^{9}$

\footnotetext{
${ }^{54}$ H. Foy „Barbed rhetoric”, Financial Times 27.11.2015.

55 „Europe's new headache. The new government in Poland has made an awful start”, The Economist 5.12. 2015.

${ }^{56}$ „The return of the awkward squad. Two weeks in, Poland's new government is making Europe nervous”, The Economist 5.12.2015.

57 „Europe's new headache. The new government in Poland has made an awful start”, The Economist 5.12.2015, za http://wiadomosci.gazeta.pl/wiadomosci/1,114871,19291093,jak-the-economist-widzi-dzispolske-6-naprawde-gorzkich-cytatow.html

${ }^{58}$ S.Ulrich “Kaczyński zerstört den polnischen Rechtsstaat”, Sueddeutsche Zeitung 23.12.2015, thum. za: http://www.pap.pl/aktualnosci/news,449879,niemieckie-media-o-polsce-polskie-wladze-przekroczylyrubikon.html

${ }^{59}$ A.Dietrich “Auf dem Weg in die nationalkonservative Diktatur", Die Welt 23.12.2015, za: http://www.pap.pl/aktualnosci/news,449879,niemieckie-media-o-polsce-polskie-wladze-przekroczylyrubikon.html
} 


\section{PUBLIC RELATIONS W INSTYTUCJACH NON-PROFIT}

\section{„Frankfurter Allgemeine Zeitung” podsumowuje:}

„Rząd PIS robi wszystko, by nie być postrzegany jako siła kształtująca politykę, lecz jako problem". ${ }^{60}$

Na szczególną uwagę zasługują materiały Fareeda Zakarii z CNN:

„Wydarzenia w Polsce przybrały bardzo brzydki obrót. Odkąd władzę w Polsce przejęła prawicowa partia Prawo i Sprawiedliwość ruszyła do wielkiego, błyskawicznego przejmowania władzy, które doprowadziło do porównań do zamachu stanu. W wątpliwym prawnie ruchu nowy parlament unieważnił wybór pięciu sędziów Trybunału Konstytucyjnego, by zrobić miejsce dla tych, którzy byliby po myśli partii.(...) To wszystko zaskakujące, ponieważ w ostatnich latach Polska była przykładem stabilności w Europie. W ciągu ostatniej dekady polskie PKB wzrosło o połowę, do kraju ściągnęly wielkie korporacje jak IKEA, Volswagen, czy Amazon. Pomimo tych sukcesów Polacy obrali „nowy kurs” i odsunęli od władzy rządzącą osiem lat Platformę Obywatelską, która wypaliła się przez skandale i złą politykę. (...) Polsce grozi 'sowiecki model cenzury', gdyż cały czas blokowane są wolne media" ${ }^{61}$

„New York Times” podsumowuje:

„Polska jest na drodze do politycznej równi pochyłej, z jakiej stacza się w objęcia brunatnej dyktatury". ${ }^{62}$

\section{I znowu Fareed Zakaria w CNN:}

„W razie zwycięstwa kandydata republikanów Donalda Trumpa Ameryka mogłaby pójść śladem Polski i Rosji, gdzie doszło do złamania demokracji. Demokracja jest krucha-spójrzcie na Polskę, Rosję i Turcję". ${ }^{63}$

Zwraca uwagę również duża szczegółowość tych tekstów. Wiele z nich na bieżąco przedstawia polityczne dyskusje w naszym kraju, sprawia wrażenie, jakby autorzy doskonale orientowali się w sekwencji wydarzeń politycznych w Polsce.

„The Economist” najczęściej publikuje teksty nie podpisane nazwiskiem autora. Jeśli chodzi o orientację w wewnętrznych sprawach naszego kraju tygodnik ten w niczym nie ustępuje największym polskim mediom. I tak w tekście „The return of the awkward squad” („Powrót kłopotliwej drużyny”) czytamy:

\footnotetext{
${ }^{60}$ R.Veser “Polen und Deutschland: ziemlich beste Freunde”, Frankfurter Allgemeine Zeitung 16.06.2016.

${ }^{61}$ F.Zakaria, CNN o Polsce, CNN, 6.12.2015, za: http://wyborcza.pl/1,75399,19304320,cnn-o-polscewydarzenia-przybraly-bardzo-zly-obrot.html.

62 "Poland's Tragic Turn", New York Times 21.12.2016.

${ }^{63}$ F. Zakaria „Global Public Square”, CNN o Polsce, CNN 6.12.2016, za: https://oko.press/demokracjakrucha-spojrzcie-polske-rosje-turcje-ekspert-cnn-zniecheca-trumpa/
} 
„Na czym się będzie opierać nowa polityka socjalna nie jest jasne. Zmiany, w szczególności zmiany emerytur są bardzo kosztowne. Proponowane opodatkowanie banków i supermarketów pokrywa jedynie w części te koszty. Deficyt budżetowy może osiągnąc $4 \%$ w przyszłym roku. W sytuacji, kiedy w Polsce mamy starzejącą się populację, a wielu młodych ludzi decyduje się na emigrację do UE, obniżenie wieku emerytalnego wydaje się być zgubne. (...) Wielu europejskich dyplomatów prywatnie jest bardzo zmartwionych". ${ }^{64}$

W „Courting disaster” („Sądowej katastrofie”) możemy przeczytać:

„Ojciec Rydzyk również jest rozczarowany nowym rządem. Po sporze o dostęp do Prezydenta zagroził PIS wstrzymaniem współpracy, mówiąc, że oczekiwał, że jego media będą traktowane w szczególny sposób. Jeszcze się okaże kogo Kaczynski i jego partia obawiają się bardziej: Unii Europejskiej czy Radia Maryja”. ${ }^{65}$

A w: „Illiberalism lives” („Nieliberalizm żyje”) stoi:

„W trakcie wysiłków pani premier Szydlo, aby pozbawić stanowiska pana Tuska, francuski ustępujący prezydent Francois Hollande powiedział ostro: może Polska ma zasady, ale UE trzyma fundusze strukturalne. W tych dniach często słyszy się takie groźby w Brukseli i Berlinie, głównie po fakcie odmowy przez Polskę i Węgry przyjęcia uchodźców. Nowe rozmowy o budżecie UE zaczynają się w przyszłym roku". ${ }^{66}$

Zagranicznym korespondentom wtórują publicyści i eksperci z Polski. Piotr Buras w artykule „Driving Poland apart” z „The New York Times” („Polska dzielona, rozbijana na pół”) stwierdza że:

„Nie to jest najgorsze, że Polska jednoczy się pod nacjonalistyczną prawicą. Najgorsze jest to, że Polska rozszczepia się pomiędzy tradycjonalizmem, a liberalizmem". 67

Zaś prof. Jadwiga Staniszkis w „Die Welt” donosi, że Jarosław Kaczyński:

$$
\text { „nie ma żadnej empatii w stosunku do swojego narodu”. }{ }^{68}
$$

Dla uważnego obserwatora codziennej sceny politycznej powyższe tezy nie będą niczym nowym. Duża część omawianych artykułów odbiła się echem w prasie polskiej; były

\footnotetext{
${ }^{64}$ „The return of the awkward squad”, The Economist 5.12.2015.

65 "Courting disaster", The Economist 2.01.2016.

66 “Illiberalism lives", The Economist 29.04.2017.

${ }^{67}$ P.Buras “Driving Poland apart”, The New York Times 23.12.2015.

68 “Kaczynski hat keine Empathie für sein Volk"- rozmowa z prof. Jadwigą Staniszkis, Die Welt 19.01.2016.
} 
one w niej szeroko komentowane. Pewnym zaskoczeniem może być jedynie fakt, że zaczyna się sugerować, iż „problemy z demokracją” nie są domeną Polski jedynie pod rządami PIS, że właściwie to Polska „nigdy wcześniej nie była prawdziwie demokratyczna”. Odmawia się demokratycznej legitymizacji całemu narodowi. W artykule z "Foreign Policy" ze stycznia 2017 roku „Poland was never democratic as it looked” ("Polska nigdy nie była tak demokratyczna, na jaka wyglądała”) Sean Hanley i James Dawson sugerują, że:

„Transformacja ustrojowa w Polsce i w innych krajach regionu nie była bardzo udana, a budowa demokracji zatrzymała się w połowie drogi. (...) Unia Europejska postawiła na niewłaściwy model demokratyzacji państw postkomunistycznych. Polityka Brukseli zawiodła, ponieważ przyjęto założenie, że demokratyzacja państwowych instytucji doprowadzi do przyjęcia demokratycznych wartości w społeczeństwie. (...) Fasadowa demokracja to wina wszystkich kolejnych rządów po 1989 roku i rok to za krótko, by zmienić cały system instytucji państwowych i wartości wyzwane przez społeczeństwo..." ${ }^{69}$

Dla polskiego inteligenta również zaskakująca będzie dychotomia ukazująca "altruistyczny zachód” kontra „ksenofobiczny wschód”. W tekście „Barbed rhetoric” („Retoryka drutu kolczastego") Henry Foy i Neil Buckley piszą:

„Po dołączeniu do Unii Europejskiej ponad dekadę temu kraje Europy Wschodniej przyjęły agendę UE, ale wzrastające obecnie nacjonalizm i antyimigrancki sentyment zatrważają ducha unijnej jedności. (....) Teraz debata kształtuje się pomiędzy altruistycznym zachodem, a ksenofobicznym wschodem. Nasze największe niebezpieczeństwo to wpaść w tę pułapkę ". ${ }^{70}$

Pejoratywnie ukazywana jest cała grupa wyszehradzka jako ta, którą cechuje „brak europejskiej solidarności”.

Sprzeciw PIS przy wyborze Donalda Tuska na kolejną kadencję przewodniczącego Rady Europejskiej (pierwszy raz państwo należące do UE nie poparło swojego kandydata) został skomentowany ironicznie. Henry Foy komentuje na Twiterze:

“Tusk wybrany ponownie na Europrezydenta, polski rząd wściekły (...) Dopiero świta wielu europejskim dyplomatom jak bardzo Tusk jest znienawidzony przez @pisorgpl \& Kaczynskiego (...) Polska premier Szydło mówi, że Polska będzie blokować konkluzje szczytu UE w tej sprawie, ale dodaje, że Polska jest szczęśliwa biorąc unijne pieniądze". ${ }^{71}$

Warto tu zadać sobie pytanie, czy przez ostatnie półtora roku można było znaleźć jakiekolwiek komentarze nt. Polski i Polaków mające wydźwięk pozytywny? Czy pojawi-

\footnotetext{
${ }^{69}$ S. Hanley, J. Dawson, „Poland was never democratic as it looked”, Foreign Policy 3.01.2017.

${ }^{70}$ H. Foy „Barber rhetoric” Financial Times, 27.11.2015.

${ }^{71}$ H. Foy https://twitter.com/henryjfoy?lang=pl 8.03.2017.
} 
ły się teksty (np. w mediach o profilu konserwatywnym), które chwaliły dokonania nowego rządu? Nie było ich wiele, jednak i takie się zdarzały.

Bank Światowy opublikował raport, w którym docenił Polskę za wprowadzenie programu 500+ dzięki któremu udało się zredukować skalę ubóstwa w Polsce 03 punkty procentowe, czyli zmniejszyć z poziomu $8,9 \%$ do $5,9 \%{ }^{72}$

Globalny strateg Morgan Stanley Investment Management Ruchir Sharma w lipcu 2017 r. na łamach amerykańskiego dziennika „New York Timesa” prognozował ekonomiczny awans Polski. W tekście „Polska nową ekonomiczną potęgą” sugerował, że:

„Spośród ponad 190 krajów, które są monitorowane przez Międzynarodowy Fundusz Walutowy, mniej niż 40 jest zaliczanych do gospodarek rozwiniętych. Reszta to gospodarki rozwijające się i wiele z nich pozostaje takimi od zawsze. Ostatnim dużym krajem z tej grupy, który przeszedł do grupy krajów rozwiniętych, była Korea Południowa, 20 lat temu. Następnym dużym narodem, który dołączy do klubu państw rozwiniętych, będzie zapewne Polska. (...) Granicą, która oddziela państwa rozwijające się od rozwiniętych, jest PKB per capita na poziomie 15 tys. dolarów. Obecnie w Polsce wynosi on 13 tys., jednak wymagany do awansu poziom zapewne zostanie przekroczony jeszcze w tej dekadzie (...)" ${ }^{73}$

Nie zapomniał o niepokojach rządów zachodnich państw i komentatorów zachodniej prasy, którzy po wygranych przez Prawo i Sprawiedliwość wyborach obawiali się wzrostu populizmu:

„chodziło o ryzyko, że nowy rząd będzie 'mieszał się’ do spraw sektora prywatnego oraz o koszty 'populistycznych' obietnic. Tyle że obawy się nie spełniły”" ${ }^{\text {,74 }}$.

Dziś wiemy, że jego prognozy się sprawdziły. Pod koniec września 2017 r. po raz pierwszy w swojej historii Polska została uznana za kraj należący nie do grupy krajów rozwijających się („,emerging markets”), a rozwiniętych (,developed markets”). Agencja indeksowa FTSE Russell uznała, że jesteśmy pierwszym środkowoeuropejskim państwem w gronie 25 najlepiej rozwiniętych krajów i od września 2018 r. będziemy znajdować się w gronie państw takich, jak np. m.in. Niemcy, Japonia i USA. ${ }^{75}$

\footnotetext{
${ }^{72}$ Karolina Goraus, Gabriela Inchauste "The Distributional Impact of Taxes and Transfers in Poland", Raport Banku Światowego, sierpień 2016, całość w:

https://openknowledge.worldbank.org/bitstream/handle/10986/24868/WPS7787.pdf?

sequence $=4 \&$ isAllowed $=\mathrm{y}$.

${ }^{73} \mathrm{http}$ :// w gospodarce.pl/informacje/38233-new-york-times-polska-nowa-ekonomiczna-potega, także: https://www.nytimes.com/2017/07/05/opinion/poland-economy-trump-russia.html

${ }^{74}$ Op.cit.

${ }^{75}$ https://www.money.pl/gielda/wiadomosci/artykul/ftse-russell-polska-rynekrozwiniety,122,0,2371450.html, https://www.gpw.pl/aktualnosc?cmn_id=10603, https://www.gpw.pl/pub/GPW/files/PDF/2017_09_FTSE_Russell.pdf
} 
Komentator polityczny BBC Andrew Marr w głośnym tekście „Dzięki Ci Polsko za przysłanie nam swojej młodzieży” z „The Sunday Times” chwalił polskich imigrantów:

„Gdybyśmy usiedli z kartką papieru i ołówkiem i spróbowali ustalić, jaki kraj byłby idealnym źródłem imigrantów dla Wielkiej Brytanii, to myślę, że po wzięciu pod uwagę wszystkich procentów, historycznych dat i ekonomicznych równań, mielibyśmy słowo Polska zaznaczone, podkreślone i opatrzone trzema wykrzyknikami.

(...) Polscy piloci walczyli w Bitwie o Anglię, a dla polskich dysydentów w czasach komunizmu i Solidarności Brytyjczycy wyrażali najgłębszy podziw. Mojemu pokoleniu jest znanych wielu polskich pisarzy i kompozytorów, m.in. Czesław Miłosz, Wisława Szymborska, Zbigniew Herbert i Witold Lutosławski, a papież Jan Paweł II traktowany był zawsze jako światowy lider o formacie Nelsona Mandeli. (...)

92 proc. imigrantów znad Wisły ma stałą pracę lub studiuje. Polacy założyli też na Wyspach ponad 22 tys. firm. (...) My pomogliśmy Polakom - przez wyższe zarobki - a oni pomogli nam. Podczas gdy Władimir Putin pręży muskuły my próbujemy ustalić nasze priorytety w procesie wyjścia z Unii Europejskiej, warto zadać sobie pytanie, kto jest naszym dobrym przyjacielem". ${ }^{76}$

Natomiast Giles Coren w zapowiadanym dzień wcześniej artykule „How to be a lazy Brit”(,Jak zostać leniwym Brytyjczykiem”) z rozkładówki z „The Times” komentował dowcipnie:

„Polacy przyjeżdżający do Wielkiej Brytanii bardzo ciężko pracują. Po kilku latach w tym kraju upodabniają się do Brytyjczyków i staja się tak samo leniwi jak oni". ${ }^{77}$

Takie komentarze trafiają się jednak w zdecydowanej mniejszości. Przez ostatnie półtora roku przeważały artykuły jednostronne, z biało-czarną tezą; najczęściej sugerujące, że Polska ma problemy z respektowaniem praworządności, wartości demokratycznych, że „stacza się w kierunku brunatnej dyktatury”. Podkreślały, że obecny polski rząd „symbolicznie opuścił flagę unijną z masztu" "78, ale mimo tego deklaruje, że „nie zamierza wprowadzać Polski z Unii Europejskiej”79 i „,chętnie bierze unijne pieniądze” ${ }^{80}$ Pojawiały się sugestie, że „inne państwa z UE chętnie zobaczyłyby Polskę poza UE". ${ }^{81}$

\footnotetext{
${ }^{76}$ Andrew Marr "Thank you, Poland, for lending us your young-a migration that really works", The Sunday Times 28.08.2016, cyt. za: http://demotywatory.pl/4685519/Brytyjski-publicysta-BBC-dziekujePolsce-Dziekuje-ci.

${ }^{77}$ Giles Coren „How to be a lazy Brit. The easy way to become a great British builder”, The Times 27.05.2017.

${ }^{78}$ H. Foy „Barber rhetoric” Financial Times, 27.11.2015.

${ }^{79}$ The Economist “Illiberalism lives”, 29.04.2017.

${ }^{80}$ H. Foy https://twitter.com/henryjfoy?lang=pl, 8.03.2017.

${ }^{81}$ The Economist "Illiberalism lives", op.cit.
} 


\section{Podsumowanie $^{82}$}

Wydaje się, że dzisiaj - ponad półtora roku po wygranych przez PIS wyborach z października 2015 apogeum niezdrowego zainteresowania Polską mamy za sobą. Aktywność zagranicznych korespondentów zdaje się tracić na sile, więc można wyciszyć emocje i powoli kusić się na podsumowania. Wciąż nie można jednak autorytatywnie stwierdzić jakie były przyczyny negatywnej kampanii prasowej na temat Polski, jak również trudno oszacować wszystkie jej konsekwencje.

Jako następstwa można wskazać zmianę wizerunku Polski na arenie międzynarodowej, niespójny i niejednoznaczny obraz Polski wśród europejskich elit politycznych, zmianę ratingów Polski w międzynarodowych instytucjach finansowych (najpierw nadanie negatywnej perspektywy, później ponowna zmiana z negatywnej na stabilną) oraz wciąż aktualną groźbę sankcji za nieprzestrzeganie praworządności (groźba zabrania bądź ograniczenia funduszy strukturalnych oraz odebrania Polsce prawa głosu w Radzie Europejskiej).

Na pewno można stwierdzić, że wbrew złowieszczym prognozom rok 2016 był dobry dla inwestycji zagranicznych w naszym kraju - wartość ogłoszonych inwestycji wzrosła o $74 \%$ w stosunku do poprzedniego roku ${ }^{83}$ Jak wynika z raportu fDi Intelligence tworzonego w pionie analitycznym Financial Times w ubiegłym roku firmy zagraniczne zapowiedziały w Polsce inwestycje o wartości 9,9 mld dolarów (co czyni $38 \mathrm{mld}$ zl). ${ }^{84} \mathrm{Szacu}-$ je się, że Polska zajęła tym piąte miejsce w Europie i osiągnęła lepszą pozycję przetargową i inwestycyjną niż wiele bogatszych krajów Europy, tj. np. Hiszpania, czy Irlandia. ${ }^{85}$ O dobrym zdaniu inwestorów na temat naszej gospodarki świadczy też ogłoszenie oceny wiarygodności kredytowej przez agencję ratingową Moody z 12 maja 2017 r. Moody utrzymała ocenę wiarygodności kredytowej Polski na poziomie A2 i co ważne - ponownie zmieniła jej perspektywę - tym razem z negatywnej na stabilną. Tym samym poprawiła jesienną niekorzystną prognozę. Oznacza to, że nie widzi zagrożenia dla spadku wiarygodności kredytowej Polski.

Również perspektywy handlu zagranicznego zapowiadają się optymistycznie dane GUS za rok 2016 pokazują wzrost polskiego eksportu o 2,3 proc. (do 183,6 mld euro), importu o 0,9 proc. (do 178,9 mld euro) oraz ponad 2 - krotne zwiększenie nadwyżki obrotów (do blisko 4,8 mld euro). ${ }^{86}$ Podczas wizyty prezydenta Chin Xi Jinpinga w Polsce w czerwcu 2016 r podpisano kilkanaście umów o charakterze bilateralnym m.in. w dziedzinie bankowości, połączeń lotniczych, a także mocno zaakcentowano rolę Polski w projekcie odbudowy nowego „Jedwabnego szlaku”, czyli drogi łączącej Chiny

\footnotetext{
${ }^{82}$ Opracowanie to nie wyczerpuje całości omawianego tematu, jest punktem wyjścia dla dalszych rozważań. Opisywanym zagadnieniom należą się w dalszym ciągu uważne obserwacje i analizy.

${ }^{83}$ Szerzej por. G. Siemiończyk „Inwestorzy cenią Polskę", Rzeczpospolita 15 maja 2017 r., również: http://www.tvp.info/30762014/inwestorzy-cenia-polske-gospodarka-sie-rozpedza

${ }^{84}$ Op.cit.

${ }^{85}$ Szerzej por.: „Zagraniczne firmy nie boją się rządu PIS”, Rzeczpospolita 15 maja $2017 \mathrm{r}$.

${ }^{86}$ https://www.mr.gov.pl/strony/aktualnosci/handel-zagraniczny-polski-w-2016-r.
} 
z Europą. Do tego we wrześniu 2017 r. po raz pierwszy w swojej historii Polska została uznana za kraj należący nie do grupy krajów rozwijających się („emerging markets), a rozwiniętych (,,developed markets”). Za rok mamy dołączyć do grona 25 najbardziej rozwiniętych państw na świecie.

Także liczba turystów napływających do Polski systematycznie się zwiększa. Ministerstwo Sportu i Turystyki podało, że w 2016 r liczba turystów z zagranicy osiągnęła dotychczasowy rekord. Wzrosła o 4,5 proc. więcej niż w 2015 r., czyli wyniosła ok. 17,5 mln (12,5 mln w samym Krakowie). ${ }^{87}$

Z cytowanych badań opinii oraz przytoczonych artykułów prasowych wynika również, że Polacy jako naród mają coraz lepszy wizerunek na Zachodzie. Budują go pracowici, dobrze wykształceni migranci, którzy coraz częściej studiują w krajach Europy Zachodniej i zajmują później wysoko wyspecjalizowane stanowiska pracy. Natomiast 'nijaki' wizerunek państwa polskiego (,Polska bez twarzy”), widoczny w badaniach opinii z ok 2010 r. został zastąpiony wizerunkiem państwa, które wprawdzie dobrze rozwija się gospodarczo, ale łamie zasady demokracji. Polska to kraj o dobrych perspektywach gospodarczych i inwestycyjnych (już nie „emerging market”, a „developed market”), ale też problemach politycznych - jest szarpana wewnętrznymi konfliktami, rządzona przez „brunatną dyktaturę”, która zablokowała Trybunał Konstytucyjny i wolne media, a swojego kandydata na szefa Rady Europejskiej nie poparła jako pierwsze państwo w historii UE. Nawet dla nawet mało uważnego obserwatora wydarzeń międzynarodowych jest to konkluzja dość przewidywalna, ale tak właśnie postrzegana jest dziś Polska na europejskiej scenie politycznej.

Pomimo licznych pozytywnych komentarzy w prasie i telewizji na temat dwóch ważnych dla Polaków wizyt (Donalda Trumpa z 6 lipca i pary książęcej Kate i Williama Windsorów z 17 lipca 2017 r., które stanowiły doskonałą promocję historii, kultury i aspiracji Polski na całym świecie), nie można uznać, że ich następstwem był przełom w pisaniu o Polsce. Po krótkich zachwytach nad Polską jako „geograficznym sercem Europy”88, „Polską jako duszą Europy” ${ }^{89}$ oraz „Polską jako wzorem i symbolem nadziei na to, że zachodnia cywilizacja przetrwa i będzie triumfować” ${ }^{90}$ oraz Polakami jako tymi, którzy „walecznie, z odwagą i determinacją walczyli o niepodległość” przywilejów, ani pieniędzy tylko Boga"92 europejską opinię publiczną przykuła kwestia reformy polskiego wymiaru sprawiedliwości. Zaczęto pisać o: „zależnym sądownictwie”"³,

\footnotetext{
${ }^{87} \mathrm{http}: / /$ tvn24bis.pl/z-kraju,74/turystyka-w-2016-r-wiecej-turystow-z-zagranicy,716615.htm

${ }^{88}$ Przemówienie Donalda Trumpa na placu Krasińskich w Warszawie z 6 lipca 2017 r., szerzej por.: https://www.wprost.pl/kraj/10063965/1/Komentarze-w-swiatowych-mediach-po-wizycie-Trumpa-w-

Warszawie-Polska-jako-przyklad.html

${ }^{89}$ Op.cit.

${ }^{90}$ Op.cit.

${ }^{91}$ Przemówienie księcia Wiliama Windsora w Pałacu Łazienkowskim w Warszawie z 17 lipca 2017 r.

${ }^{92}$ Przemówienie Donalda Trumpa, op.cit.

93 „Dependent judicary: Populism in Poland”, The Economist 22.07.2017.
} 


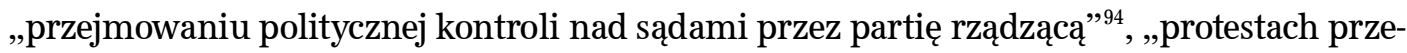
ciwko polityce partii rządzącej, które miały miejsce w ponad 220 miastach w Polsce od Helu po Zakopane" ${ }^{\text {"95 }}$. Po podjęciu weta przez prezydenta Andrzeja Dudę 24 lipca br. napisano: „przejmowanie sądownictwa w Polsce zostało na chwilę wstrzymane, ale rządy prawa w Polsce nadal są zagrożone". ${ }^{96}$ Nie wszystkie komentarze były tak eleganckie. Szerokim echem wśród polskich internautów odniósł się komentarz norweskiego dziennikarza na temat weta prezydenta Dudy:

$$
\text { „Pies Kaczyńskiego stał się mężczyzną”. } 97
$$

Tak więc w żadnej mierze nie możemy mówić o przełamaniu niekorzystnej narracji i zmianie stylu pisania o Polsce. Dlatego doniesieniom medialnym należy nadal przyglądać się z należytą uwagą. Wszak „wizerunek danego kraju jest pewnego rodzaju walutą, którą można wymienić na inne dobra: współpracę polityczną dla realizacji celów, (...) napływ inwestorów, możliwości eksportowe, zainteresowanie turystów, konsumentów kultury...”. ${ }^{98}$ Należy wciąż przypominać, że dbałość o wizerunek Polski na arenie międzynarodowej pozostaje ważnym zadaniem nie tylko dla elit, czy decydentów politycznych, ale wszystkich świadomych obywateli naszego kraju.

\section{BIBLIOGRAFIA:}

\section{BADANIA OPINII PUBLICZNEJ:}

„How Europeans see themselves: looking through the mirror with public opinion surveys", European Commission, Luxemburg 2001.

„Eye on Poland. Promocja i wizerunek Polski w oczach międzynarodowych ekspertów marketingu miejsc”, BEST PLACE- Europejski Instytut Marketingu Miejsc, styczeń 2012.

Badanie opinii „Określenie wizerunku, który Polska powinna promować za granicą", Laboratorium Badań Społecznych dla MSZ, Warszawa, listopad 2013.

„Barometr Polska-Niemcy”, Instytut Spraw Publicznych, jesień 2013.

Stereotyping in Europe, Pew Reseach Center 2012 i 2013.

Livewhat, Geneva-based survey, cyt. za: “Green-eyed continent”, The Economist 29 marca 2016.

Standard Eurobarometr nr 86, Europeans' opinion of the EU's priorities, listopad 2016.

\footnotetext{
94 „Dependent judicary: Populism in Poland”, op.cit.

95 „Objection sustained: Illiberalism in Poland”, The Economist 29.07.2017.

96 „Objection sustained: Illiberalism in Poland, op.cit.

${ }^{97}$ https://wiadomosci.wp.pl/skandaliczne-slowa-norweskiego-dziennika-o-dudzie-lawina-komentarzy6148287146247809 a

${ }^{98}$ W. Olins, badanie opinii „Określenie wizerunku...”, Laboratorium Badań Społecznych dla MSZ, Warszawa, listopad 2013, s. 13.
} 


\section{MATERIALY PRASOWE POLSKIE:}

Bachman K. „Wejście po przejściach”, Polityka 20 lipca 2002.

Bielecki J., Stankiewicz A. „Witajcie w Unii, jeśli musicie”, Rzeczpospolita 26 kwietnia 2002.

Dawidowski A. „Żadnych złudzeń”, Unia i Polska 23 października 2000.

Dessler J. „Komisja Europejska o przywarach Polaków”, PAP lipiec 2001.

Grzeszak A. „Poland- gdzie to jest? Przymiarka do marki”, Polityka 25 maja 2002.

Saryusz Wolski J. „Ekonomiczny apartheid”, Die Welt 28 listopada 2002.

Skotnicka-Illasiewicz E. „Swojska kultura lękliwości. O sposobach postrzegania UE przez Polaków i unitów”, Unia i Polska 3 września 2001.

Smoczyński W. „Polska - kraj bez twarzy”, Polityka 30 czerwca 2009.

„UE- Polak to pazerny fatalista”- serwis informacyjny Wirtualnej Polski z 25 lipca 2001.

Swieżewska D. ,Jak postrzegają nas Brytyjczycy, czyli wizerunek Polaka na Wyspach"w: http://polemi.co.uk/lajt/artykuly/wizerunek-polakow-wwielkiej-brytanii-5511, www.kobietawuk.info.

Siemiończyk G. „Inwestorzy cenią Polskę”, Rzeczpospolita 15 maja 2017.

\section{MATERIAEY PRASOWE OBCOJEZZYCZNE:}

Blankley T. „France blackmails Poland”, The Washington Times 19 lutego 2002.

Buras P. “Driving Poland apart”, The New York Times 23 grudnia 2015.

Coren G.,,How to be a lazy Brit. The easy way to become a great British builder", The Times 27 maja 2017.

"Courting disaster", The Economist 2 stycznia 2016.

„Dependent judicary: Populism in Poland”, The Economist 22 lipca 2017.

Diehl J. "Poland's disturbing tilt to the right", The Washington Post 29 listopada 2015.

„Europe's new headache. The new government in Poland has made an awful start", The Economist 5 grudnia 2015.

Dietrich A. "Auf dem Weg in die nationalkonservative Diktatur", Die Welt 23 grudnia 2015, cyt. za:

http://www.pap.pl/aktualnosci/news,449879,niemieckie-media-opolsce-polskie-wladze-przekroczyly-rubikon.html

Foy H. „,Barbed rhetoric”, Financial Times 27 listopada 2015.

"Green-eyed continent", The Economist 29 marca 2016.

Hanley S., Dawson J., „Poland was never democratic as it looked”, Foreign Policy 3 stycznia 2017.

"Illiberalism lives", The Economist 29 kwietnia 2017.

"Kaczynski hat keine Empathie für sein Volk"- rozmowa z prof. Jadwigą Staniszkis, Die Welt 19 stycznia 2016 r. 
Marr A. "Thank you, Poland, for lending us your young - a migration that really works", The Sunday Times 28 sierpnia 2016, cyt. za: http://demotywatory.pl/4685519/Brytyjski-publicysta-BBC-dziekujePolsce-Dziekuje-ci.

„Objection sustained: Illiberalism in Poland”, The Economist 29 lipca 2017. Santoso A. „Greek Think They're the Hardest Working People in Europe”, The Economist 4 czerwca 2012.

Sharma Ruhir "The Next Economic Powerhouse? Poland", The New York Times 5 lipca 2017.

„The return of the awkward squad. Two weeks in, Poland's new government is making Europe nervous", The Economist" 5 grudnia 2015.

Ulrich S. "Kaczyński zerstört den polnischen Rechtsstaat", Sueddeutsche Zeitung 23 grudnia 2015, cyt. za: http://www.pap.pl/aktualnosci/news,449879,niemieckie-media-o-polsce-polskie-wladze-przekroczyly-rubikon.html

Veser R. "Polen und Deutschland: ziemlich beste Freunde", Frankfurter Allgemeine Zeitung 16 czerwca 2016.

Zakaria F., CNN o Polsce, CNN, 6 grudnia 2015, cyt. za: http://wyborcza.pl/1,75399,19304320,cnn-o-polsce-wydarzenia-przybraly-bardzo-zly-obrot.html.

“Poland's Tragic Turn”, New York Times 21 grudnia 2016.

Zakaria F. „Global Public Square”, CNN o Polsce, CNN 6 grudnia 2016, cyt. za: https://oko.press/demokracja-krucha-spojrzcie-polske-rosje-turcjeekspert-cnn-zniecheca-trumpa/

\section{LITERATURA:}

Balzer A. "Just A Platonic Love?- Poland and the EU Enlargement" w: "Poland and the Czech Republic: Advocates of the EU Enlargement?' wyd. Demos EUROPA Center for European Strategy Warszawa 2010.

Bond I. “EU Enlargement”, Center for European Reform, www.cer.org.uk.

Fomina J.,Frelak J. „Wizerunek Polski i Polaków w Wielkiej Brytanii”, wyd. ISP 2011.

Goraus K., Inchauste G. "The Distributional Impact of Taxes and Transfers in Poland", Raport Banku Światowego, sierpień 2016.

Holzer J. „Polacy i Niemcy- wzajemne postrzeganie”, „Kultura i społeczeństwo", tom XLI, wyd. ISP PAN 1997.

Kolarska-Bobińska L. „Odmienność oswajana. Obraz Polski w krajach Unii Europejskiej”, wyd. Instytut Spraw Publicznych, Warszawa 2003.

Koves A. „Central and Eastern European Economies in Transition. The International Dimension”, Westview Press, San Francisco 1992.

Martinez Reyes V. „Reguły gry, czyli o negocjacjach akcesyjnych i łączeniu się Europy", Wyd. Naukowe Scholar, Warszawa 2000. 


\section{PUBLIC RELATIONS W INSTYTUCJACH NON-PROFIT}

Niklewicz K. „Przewodnictwo Polski w Radzie Unii Europejskiej”, 2013.

Ollins W. „Tożsamość rynkowa. Atrybut konkurencyjnego Państwa”, wyd. Instytut Marki Polskiej, Warszawa 2001.

Płonka B. „Polityka Unii Europejskiej wobec krajów Europy Środkowej”, wyd. UJ, Kraków 2003.

Sedelmeier U. „Europe after the Eastern Enlargement of the European Union: 2004-2014", Heinrich Boell Stiftung 2014.

"The EU Capacity for Futher Enlargeement" nr 71, Advisory Council on International Affairs 2010 w: http://aiv-advies.nl/download/1b2da5920f83-4791-b83f-fe822471ff84.pdfs

Walkiewicz W. : „Polska na drodze do Unii Europejskiej. Aspekty negocjacyjne i dostosowawcze", wyd. Rzeszów 2002.

Warchala M. (red). „Wizerunek Polski w prasie krajów Unii Europejskiej”, wyd. Instytut Spraw Publicznych, Warszawa 2002.

Wnuk- Lipiński E. „Członkostwo Polski w Unii Europejskiej-pierwsze Problemy i kryzysy społeczne w Polsce”, w: „Polska w Unii Europejskiej. Początkowe problemy i kryzysy?”, wyd. PISM, Warszawa 2002.

\section{OAUTORCE:}

Dr Karolina Swirska-Czalbowska jest wykladowcą Uniwersytetu Stefana Kardynała Wyszyńskiego. Publikowała m.in. w „Polis - piśmie o sztuce życia publicznego”, wyd. przez ISP PAN, kwartalniku CE UW, „Studia europejskie”, „Problemach zarządzania”, "Studiach i materialach", Raporcie INE PAN, również w Magazynie Niezależnych Publicystów „Unia i Polska”, „Tygodniku Powszechnym” $i$ „Arcanach”. Jej zainteresowania naukowe obejmują wizerunek Polski i Polaków poza granicami naszego kraju, kwestie budowania marki narodowej, brandingu narodowego i narodowej tożsamości rynkowej, a także promocji Polski w Świecie w sferze kulturalnej, politycznej i gospodarczej. Kontakt:kswirska@wp.pl

Dane wartykule - stan na 1 października $2017 \mathrm{r}$. 